\title{
Copyright's Topography: An Empirical Study of Copyright Litigation
}

\section{Christopher A. Cotropia ${ }^{*} \&$ James Gibson ${ }^{* *}$}

One of the most important ways to measure the impact of copyright law is through empirical examination of actual copyright infringement cases. Yet scholars have universally overlooked this rich source of data. This study fills that gap through a comprehensive empirical analysis of copyright infringement litigation, examining the pleadings, motions, and dockets from more than nine hundred copyright lawsuits filed from 2005 through 2008. The data we collect allow us to examine a wide variety of copyright issues, such as the rate of settlements versus judgments; the incidence of litigation between major media companies, small firms, and individuals; the kinds of industries and works involved in litigation; the nature of the alleged infringement; the success rates of particular parties and claims; and the nature of remedies sought and awarded. We also analyze the data to identify ways in which copyright litigation differs from other civil suits and to show that certain plaintiff characteristics are more predictive of success.

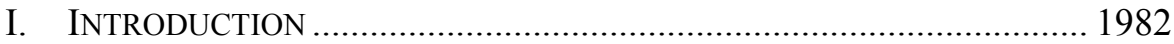

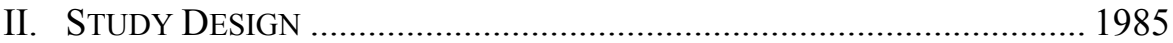

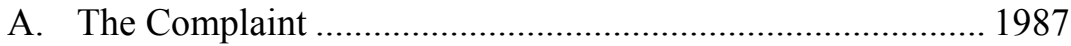

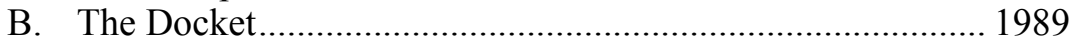

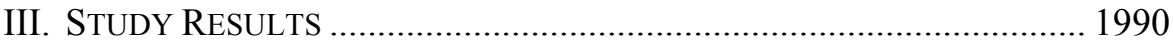

A. Commonplace and Performing Rights Cases....................... 1991

1. Complaint Content........................................................ 1991

a. Party Characteristics ................................................. 1991

b. Nature of Disputes...................................................... 1996

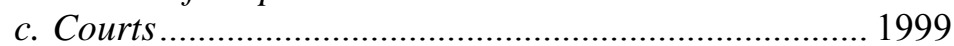

2. Course of Litigation ....................................................... 2000

a. Defendant's Response .............................................. 2000

b. Activity During the Case's Pendency.......................... 2000

\footnotetext{
* Professor of Law and Austin Owen Research Fellow, University of Richmond. We would like to thank David Abrams, Robert Bone, Jessica Erickson, Paul Heald, Justin Hughes, Jay Kesan, Corinna Lain, Glynn Lunney, Rob Merges, Mark Michaels, Dotan Oliar, Kristen Osenga, Lee Petherbridge, Matt Sag, Pam Samuelson, David Schwartz, Michal Shur-Ofry, Rob Tyler, Amy Whitelaw, and participants at the 2013 Intellectual Property Scholars Conference, the 2013 University of Richmond Summer Colloquy series, the October 2013 Thomas Jefferson Intellectual Property Inn of Court, and the Texas Law Review's 2014 Symposium on "Steps Toward EvidenceBased IP." We would also like to acknowledge the invaluable support of George Mason University's Center for the Protection of Intellectual Property and its Leonardo da Vinci Research Grants.

**Associate Dean for Academic Affairs and Professor of Law, University of Richmond. In addition to those acknowledged above, Jim would like to thank his personal topographist, Jane Savoca.
} 


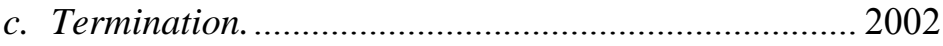

d. Remedies Granted ...................................................... 2003

B. FILE SHARING CASES.................................................................... 2004

1. Complaint Content ........................................................... 2004

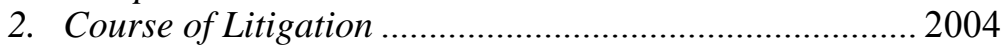

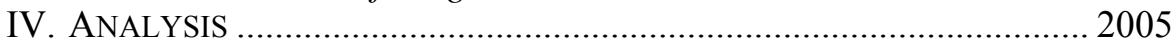

A. Comparing Copyright Cases to Other Civil Litigation ......... 2005

1. Geographic Distribution of Cases .................................. 2006

2. Percentage and Magnitude of "Difficult" Cases ............. 2009

3. Termination ....................................................................... 2011

B. The Role of Party Size and Industry .................................. 2012

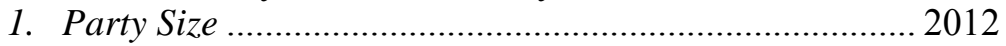

2. Party Industry (High-IP and Low-IP) .......................... 2016

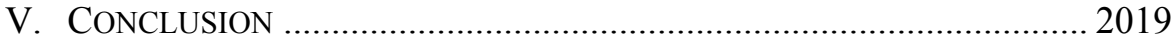

APPENDIX A: CODED FIELDS …........................................................ 2020

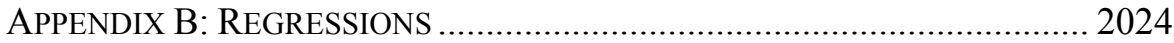

\section{Introduction}

Copyright reform is in the air. The Register of Copyrights has called for an across-the-board reexamination of the federal copyright statutesomething that has not happened since the 1970s. ${ }^{1}$ A team of academics, practitioners, and industry experts has produced The Copyright Principles Project: Directions for Reform, the culmination of three years of inquiry into "how current copyright law could be improved and how the law's current problems could be mitigated." 2 Most important, Congress has started to show interest: the chairman of the House Judiciary Committee recently announced "a wide review of our nation's copyright laws and related enforcement mechanisms" ${ }^{3}$ and has begun to hold a comprehensive series of hearings on U.S. copyright law. ${ }^{4}$

Despite these calls for reform, there is much we do not know about how current law actually handles copyright cases. Empirical studies of copyright litigation are almost completely nonexistent. Some work has

1. See generally Maria A. Pallante, The Next Great Copyright Act, 36 COLUM. J.L. \& ARTS 315 (2013) (setting out in detail the problems with the current copyright statute and the Register of Copyrights's vision for overhauling the statute and Copyright Office).

2. Pamela Samuelson et al., The Copyright Principles Project: Directions for Reform, 25 BERKELEY TECH. L.J. 1175, 1176 (2010).

3. Press Release, House Judiciary Comm., Chairman Goodlatte Announces Comprehensive Review of Copyright Law (Apr. 24, 2013), available at http://judiciary.house.gov/index.cfm/ 2013/4/chairmangoodlatteannouncescomprehensivereviewofcopyrightlaw.

4. Press Release, House Judiciary Comm., Subcommittee to Hold First Hearing on Comprehensive Copyright Review (May 15, 2013), available at http://judiciary.house.gov/ index.cfm/2013/5/subcommitteetoholdfirsthearingoncomprehensivecopyrightreview. 
been done on how courts decide fair use claims ${ }^{5}$ and others are studying copyright registrations, ${ }^{6}$ but other than that the field stands empty. ${ }^{7}$ Who files copyright cases? What kinds of works are involved — software, books, music, film? What claims are made? How many cases go to trial? What remedies are awarded? Are some courts more favorable to claimants? No one knows the answer to these and other fundamental questions about the workings of our copyright system. This deficiency is in sharp contrast to the empirical studies done on patent litigation, which have been numerous, deep, and varied. ${ }^{8}$

5. See generally Barton Beebe, An Empirical Study of U.S. Copyright Fair Use Opinions, 1978-2005, 156 U. PA. L. REV. 549 (2008) (conducting an empirical analysis of the treatment of fair use doctrine in federal courts and prescribing solutions to the variance in applicability among lower courts); Neil Weinstock Netanel, Making Sense of Fair Use, 15 LEWIS \& CLARK L. REV. 715 (2011) (examining prior quantitative studies of the fair use doctrine, the history of the fair use doctrine, and leading fair use cases, and concluding that the "transformative use" standard has become dominant in recent years); Matthew Sag, Predicting Fair Use, 73 OHIO ST. L.J. 47 (2012) (asserting, based on original empirical analysis, that the fair use doctrine is not as incoherent and unpredictable as other scholars have claimed).

6. See generally Dotan Oliar \& Nicholas Matich, Copyright Preregistration: Evidence and Lessons from the First Seven Years, 2005-2012, 55 ARIZ. L. REV. 1073 (2013) (studying the preregistration of copyrighted works between 2005 and 2012, and recommending policy adjustments based on both original quantitative and qualitative data); Dotan Oliar et al., Copyright Registrations: Who, What, When, Where, and Why, 92 TEXAS L. REV. 2211, 2213-14 (2014) (examining both the geographic and demographic nature of copyright registrants and concluding that firms often register "motion pictures, serials, and computer files" whereas individuals tend to register "text and music").

7. Note, however, that scholars have done some interesting and fruitful empirical work in copyright outside the litigation context. See generally Christopher Buccafusco \& Christopher Jon Sprigman, The Creativity Effect, 78 U. CHI. L. REV. 31 (2011) (demonstrating the existence of a "creativity effect," a valuation anomaly that is distinct from and more intense than the traditional endowment effect, whereby creators of work value their creations substantially more than buyers or mere owners of the work); Peter DiCola, Money from Music: Survey Evidence on Musicians' Revenue and Lessons about Copyright Incentives, 55 ARIZ. L. REV. 301 (2013) (studying the role of copyright law an as incentive for musicians); Paul J. Heald, How Copyright Makes Books and Music Disappear (and How Secondary Liability Rules Help Resurrect Old Songs) (Ill. Program in Law, Behavior and Soc. Sci., Paper No. LBSS14-07, 2014), available at http://www.law.illinois .edu/iplbss/page/papers.aspx (studying the availability of books and songs on Amazon.com and YouTube, respectively, and arguing that copyright law stifles distribution and market availability); Glynn S. Lunney Jr., Empirical Copyright: A Case Study of File Sharing and Music Output (Tulane Univ. Sch. of Law Pub. Law and Legal Theory Working Paper Series, Working Paper No. 14-2, 2014), available at http://papers.ssrn.com/sol3/papers.cfm?abstract_id $=2372630$ (concluding that, while file sharing has reduced the number of new artists to breach the Billboard Hot 100 's top fifty list, file sharing has not reduced the creation of new original music).

8. See generally John R. Allison et al., Valuable Patents, 92 GEO. L.J. 435 (2004) (asserting that "some patents are intrinsically more valuable than others" and identifying characteristics of the most valuable and, subsequently, most litigated patents); Christopher A. Cotropia \& Mark A. Lemley, Copying in Patent Law, 87 N.C. L. REv. 1421 (2009) (finding that few patent cases involve allegations or offer proof of copying and that even fewer reported cases made a finding regarding copying); Jay P. Kesan \& Gwendolyn G. Ball, How Are Patent Cases Resolved? An Empirical Examination of the Adjudication and Settlement of Patent Disputes, 84 WASH. U. L. REV. 237 (2006) (making numerous findings, including that final rulings on the merits via summary judgment are more common and important than previously suggested and that even 
This Article is a first step in addressing the absence of empirical research on copyright litigation. It presents the results of a study of almost one thousand copyright cases - and by "cases" we mean not published judicial opinions, but actual dockets and the complaints and other documents they contain. ${ }^{9}$ We examined the dockets, read the pleadings, and coded 46 different fields and 125 different variables in each case. The result is a topography of copyright litigation, a broad look at the legal landscape in which copyright disputes are resolved. Our goal in taking such a broad-brush approach is to provide both a basis for an overall understanding of copyright litigation and a foundation for future research on more specific topics. (Future researchers may access our data at copyrightlawdata.com.)

That said, even this initial foray has produced some interesting results. We confirm the popular belief that the Central District of California and Southern District of New York are "hot districts" for copyright cases, but the data indicate that cases in those districts are less likely to result in a plaintiff win. We find that while copyright cases are no more likely to get contentious than other civil litigation, when they do get contentious, they get very contentious-resulting in significantly more docket entries, substantive rulings, and trials. Finally, we find a surprisingly high number of small firms and "low-IP" industries to be prominent (and successful) in

pretrial rulings on the merits may not necessarily reduce the cost of pursuing the patent infringement claim); Jean O. Lanjouw \& Mark Schankerman, Characteristics of Patent Litigation: A Window on Competition, 32 RAND J. ECON. 129 (2001) (showing substantial and predictable variation across patents in their exposure to litigation risks based upon the species of patented material, e.g., drug or health patents); Jean O. Lanjouw \& Mark Schankerman, Protecting Intellectual Property Rights: Are Small Firms Handicapped?, 47 J.L. \& ECON. 45 (2004) (providing empirical data and analysis to show that a large patent portfolio reduces the probability of litigating any discrete patent within the portfolio, that this "portfolio effect" is stronger for small firms, and that increased interaction increases cooperation between firms); Shawn P. Miller, What's the Connection Between Repeat Litigation and Patent Quality? A (Partial) Defense of the Most Litigated Patents, 16 STAN. TECH. L. REV. 313 (2013) (arguing that owners who repeatedly pursue infringement claims will be successful); Kimberly A. Moore, Forum Shopping in Patent Cases: Does Geographical Choice Affect Innovation?, 79 N.C. L. REV. 889 (2001) (studying how procedural and substantive differences among district courts encourage forum shopping and how forum shopping has continued despite the creation of the Federal Circuit); Kimberly A. Moore, Judges, Juries, and Patent Cases-An Empirical Peek Inside the Black Box, 99 MiCH. L. REV. 365 (2000) (suggesting that latent biases, which deferential-review standards mask, may pervade the jury-trial system for patent infringement suits); Deepak Somaya, Strategic Determinants of Decisions Not to Settle Patent Litigation, 24 StrategiC MgmT. J. 17 (2003) (proposing two motivation forces for the nonsettlement of patent suits: the strategic stakes a firm has in the litigated patent and the ability of competing firms to "mutually block" patent rights through litigation).

9. As Margo Schlanger and Denise Lieberman have pointed out, "for anyone who hopes to understand litigation ... there is no substitute for court records." Margo Schlanger \& Denise Lieberman, Using Court Records for Research, Teaching, and Policymaking: The Civil Rights Litigation Clearinghouse, 75 UMKC L. REV. 155, 168 (2006); see also David A. Hoffman et al., Docketology, District Courts, and Doctrine, 85 WASH. U. L. REV. 681, 684-86 (2007) (discussing the importance of conducting empirical research using entire trial court dockets). 
litigation. ${ }^{10}$ In contrast, major media plays a smaller role than expected, and individuals and authors are active as plaintiffs but tend to do poorly.

Of course, we focus here only on the world of litigation. Court cases represent only one component in copyright's legal regime. Some of the law's effect is felt at the ex ante incentive level, and much interaction between rightholders and users takes place through licensing rather than through litigation. ${ }^{11}$ But "[t]he courtroom is the crucible of the law," where legal mechanisms undergo their most thorough and deliberate testing. ${ }^{12}$ What we know about the workings of actual copyright cases tells us a great deal about the workings of copyright law overall.

The Article proceeds as follows. Part II describes the design of the study. Part III presents our descriptive data along several different dimensions: characteristics of the parties, industries, works, claims, resolutions, and remedies, to name just a few. Part IV then analyzes the descriptive data, using correlations and regressions, and explores two particular topics: key differences between copyright litigation and other civil cases, and the effect of party composition on the success rate of infringement claims.

\section{Study Design}

We began by identifying the relevant population: all cases filed in federal court from January 1, 2005 to December $31,2008^{13}$ where the "Nature of Suit" was Copyright. ${ }^{14}$ We used Bloomberg Law's Docket

10. "Low-IP" refers to fields in which creative innovation is said to occur without much or any copyright protection. See Kal Raustiala \& Christopher Springman, The Piracy Paradox: Innovation and Intellectual Property in Fashion Design, 92 VA. L. REV. 1687, 1718 (2006) (claiming that the relative lack of IP protections in the fashion industry has not stifled innovation and may in fact serve the industry's interests).

11. See, e.g., James Gibson, Risk Aversion and Rights Accretion in Intellectual Property Law, 116 YALE L.J. 882, 899-903 (2007) (discussing the effect of licensing on the development of copyright law).

12. James Gibson, A Topic Both Timely and Timeless, 10 RICH. J.L. \& TECH. 49, 11 (2004).

13. We chose a multiyear period so that the data would be less influenced by fleeting trends in litigation and thus more representative of typical litigation patterns. We chose 2005 to 2008 rather than a more recent time period because we wanted to maximize the chances that the cases had terminated, as one of our goals is to study a number of variables associated with termination. And we chose federal court because federal jurisdiction over copyright claims is exclusive. See 28 U.S.C. § 1338(a) (2012).

14. Lawsuits filed in federal court are assigned a "Nature of Suit" code. We searched for cases where the code was 820, which identifies the case as involving Property Rights - Copyright. Use of this code is common in constructing litigation studies focused on a particular subject matter. See, e.g., Kesan \& Ball, supra note 8, at $260 \mathrm{nn} .177-78$ (using code 830 for cases involving Property Rights-Patent). While this methodology may miss some copyright cases that were not properly identified as 820 cases, the number is likely negligible. See Matthew Sag, Empirical Studies of Copyright Litigation: Nature of Suit Coding 7 (Loyola Univ. Chi. Sch. of Law Pub. Law \& Legal Theory, Research Paper No. 2013-017, 2013), available at http://ssrn.com/abstract=2330256 (finding that 820 coding "is a good enough sample for most 
Search to formulate this list, which ultimately totaled 17,119 cases. ${ }^{15}$ We then randomly pulled 1,077 cases from this list, of which we ultimately coded 957 in depth. ${ }^{16}$ Of those 957 cases, 294 were filed in 2005, 267 were filed in 2006, 206 were filed in 2007, and 190 were filed in $2008 .^{17}$

For each case, including those not coded in depth, we used a computer-automated script to extract the case name, the filing date, the docket number, the name of the court in which the case was filed, the name of the judge, the names of the parties, and a hyperlink to the case's docket on Bloomberg Law. Then we coded the randomly selected cases by hand in two stages - first focusing on the content of the latest-filed complaint and then focusing on the other docket entries in the case. ${ }^{18}$ A complete list of fields coded and the data category for each field is available in Appendix A.

purposes").

15. Bloomberg Law's Docket database mirrors the federal court system's PACER database. Bloomberg obtains docket information and docket filings directly from PACER. Elizabeth Y. McCuskey, Clarity and Clarification: Grable Federal Questions in the Eyes of Their Beholders, 91 NeB. L. REV. 387, 443 (2012). The specific search limited the request to "U.S. District Court," with "Nature of the Suit" being "Property Rights - Copyrights [820]" and a filing date range between January 1, 2005 and December 31, 2008. Our 17,119 figure is comparable to the statistics from the Administrative Office of the United States Courts, which reported 17,371 copyright cases filed during the same time period. See infra note 65 (listing the specific databases consulted in obtaining the Administrative Office figure).

16. We discarded 111 cases because no complaint was available (on Bloomberg or on PACER), 8 cases because they had been misidentified as copyright cases, and 1 case because it was duplicative of a case already in the data set (having been transferred from one district to another and assigned a new docket number). Of the 111 cases for which no complaint was available, 43 were filed in 2005, 33 were filed in 2006, 34 were filed in 2007, and 1 was filed in 2008. Most were filed in various divisions of the Central District of California ( 72 cases) with the next-highest number being filed in the Southern District of New York ( 9 cases). Only 3 were filed in the Northern District of California.

17. This distribution mirrors the filing intensity of File Sharing cases, with most of those cases being filed in the earlier years of the period we studied. The distribution of the 383 Commonplace cases we coded was 91 cases in 2005, 86 cases in 2006, 87 cases in 2007, and 119 cases in 2008. See infra text accompanying note 32 (providing the authors' description of File Sharing and Commonplace cases).

18. We coded the complaints and dockets ourselves. To test our intercoder agreement, we both coded twenty of the same cases and selected Cohen's Kappa as the measure of intercoder agreement. See Mark A. Hall \& Ronald F. Wright, Systematic Content Analysis of Judicial Opinions, 96 CALIF. L. REV. 63, 113-14 (2008) (explaining that the best practice for measuring and quantifying the reliability of intercoder agreement is to use a coefficient such as Cohen's Kappa, which measures the reliability of agreement between coders and controls for agreement that occurs purely by chance). Cohen's Kappa ranges from 0 to 1 , with numbers near 1 indicating a higher degree of reliability. Id. Our Cohen's Kappa for the coded variables ranged from 1, which equates to "perfect agreement," to 0.799 , which translates to "substantial agreement." Anthony J. Viera \& Joanne M. Garrett, Understanding Interobserver Agreement: The Kappa Statistic, 37 FAM. MED. 360, 361-62 \& tbl.2 (2005). The mean Cohen's Kappa was 0.931, which equates to "almost perfect agreement." Id. at 362 tbl.2. While the few disagreements were resolved, this level of intercoder agreement both provided information about the reliability of the data measurement system being used and facilitated feedback between the coders to ensure even greater reliability. 


\section{A. The Complaint}

We began with the latest-filed complaint for each case. ${ }^{19}$ We first coded the characteristics of the parties: the number of plaintiffs, number of defendants, and number of defendants that the plaintiffs identified as "Does." We then added the industries for plaintiff and defendant ${ }^{20}$ as well as their sizes - either individuals, small firms, or Fortune 1000 companies (and their subsidiaries). ${ }^{21}$ We also coded whether any of the plaintiffs was the author of the copyrighted work or works. ${ }^{22}$

Next, we coded information on the copyrighted works at issue in the case: the number of works and their subject matter. ${ }^{23}$ We also used the subject-matter classification to generate a binary field called "high

19. The latest filed and available complaint was used when coding; however, when tallying the number of parties, we would include any party named in any complaint, regardless of when it was filed.

20. The coding for industry focused on the industry of the largest plaintiff or defendant, not the industry of the copyrighted work or works at issue. For some cases, these were one and the same; for others, they were different.

21. If there were multiple plaintiffs or defendants, size was coded based on the largest plaintiff and largest defendant. Doe defendants were coded as individuals. The Fortune 1000 size classification was based on the Fortune 1000 list for the year the case was filed. The Small Firm category included any party that was not an individual or a Fortune 1000 company (or subsidiary). That might seem to stretch the meaning of the term "small firm," but in fact such parties were almost always private-sector entities; the only exceptions involved one case with a public-sector plaintiff (a New York county) and two with public-sector defendants (a school district and a Texas city). That said, Small Firm would also include companies whose revenues are sufficient to put them in the top 1,000, but which are kept off Fortune's list for other reasons (e.g., because the firms do not file with any U.S. government agency). See How We Pick the 500, CNN MONEY, http://money.cnn.com/magazines/fortune/global500/2013/faq/ (noting that to make the Fortune 500 list companies "must publish financial data and report part or all of their figures to a government agency").

22. While coding, we called this field "Plaintiff_Creator," but "author" accurately describes the coding criteria, so we use the latter term here.

23. Our subject-matter categories were initially based on the Copyright Act's statutory classifications in 17 U.S.C. $\S 102$ (a) (2012), but we then broke down those categories into more specific subsets. Our reasoning is that the Copyright Act's statutory scheme sometimes combines dissimilar works into one category. For example, the Act considers both books and software to be "Literary Works." See id. $\S 101$ (providing a definition of "Literary works" that includes software because the work may be expressed in "words, numbers, or other verbal or numerical symbols ... regardless of the nature of the material objects"); see also 37 C.F.R. §202.3(b)(i) (2008) (instructing that "Class TX" includes "all published and unpublished nondramatic literary works"). So it made sense to take a more granular approach. If multiple subject matters were at issue, then subject matter was coded as Multiple-Musical Work and Sound Recording, Multiple-Website, or Multiple - Other. The specific subject matter of the work at issue was determined by looking at the description in the complaint and, if attached, the copyright registration. Although we had hoped to compare our data to data from Copyright Office registrations, the Copyright Office uses a smaller (and frankly less illuminating) set of subject matter categories: nondramatic literary works, works of performing arts, works of visual arts, sound recordings, and serial works (i.e., periodicals). Id. § 202.3(b). 
authorship," as distinguished from "low authorship" works that require effort but little creativity. ${ }^{24}$

We then looked into the overall nature and purpose of the suit. We began by determining whether the complaint involved a declaratory judgment, in which the plaintiff was allegedly threatened with a claim of infringement by the defendant. ${ }^{25}$ We also recorded whether the complaint included a dispute over copyright ownership and any claims based on state law or foreign copyright. ${ }^{26}$

We next identified the particulars of each cause of action. First, we determined which specific subparts of 17 U.S.C. $\S 106$ were the bases for any copyright infringement claims. ${ }^{27}$ Next, we examined whether the complaint asserted other federal copyright claims, including any secondary liability claim, any Visual Artists Rights Act (VARA) claim under $\S 106 \mathrm{~A},{ }^{28}$ and any claim under the Digital Millennium Copyright Act (DMCA) - either fraudulent takedown liability under $\S 512,{ }^{29}$ anticircumvention liability under $\S 1201,{ }^{30}$ or copyright management information liability under $\S 1202 .{ }^{31}$ We also identified and coded noncopyright claims in three categories: (1) trademark infringement (including

24. High Authorship included all subject matters except Architectural, Literary-Industry Publications, Literary-Software, PGS-Apparel/Fashion/Textiles, and PGS-Industrial. See Jane C. Ginsburg, Creation and Commercial Value: Copyright Protection of Works of Information, 90 COLUM. L. REV. 1865, 1870 (1990) (distinguishing between "high authorship" and "low authorship" and using the term "low authorship" to describe works that require much effort but little creativity). More recent scholarship might call these "high-IP" and "low-IP" works. See supra note 10.

25. For purposes of this study, a case was identified as involving a declaratory judgment only when the complaint alleged that the defendant had accused the plaintiff of copyright infringement. In those cases, we reversed the party coding, so that the plaintiff would be coded as defendant, claims would be coded as counterclaims, and so forth. (Other types of declaratory judgments could be at issue in any of the cases in the study, but those falling outside this definition were not coded as such.)

26. Under foreign claims we also included claims alleging infringement of a foreign work under U.S. copyright law.

27. A case could be coded as alleging a claim under a particular subsection of $\S 106$ even if the complaint did not explicitly cite that subsection. For example, a claim would be coded under $\S 106(3)$ if the defendant was accused of "distribut[ion]" or "sale" of the copyright work. 17 U.S.C. $\S 106(3)$ (2012). Coding was a particular challenge for adaptation claims under $\S 106(2)$, as they could always be articulated as mere reproduction claims. We encountered no cases like Mirage Editions, Inc. v. Albuquerque A.R.T. Co., 856 F.2d 1341 (9th Cir. 1988), in which the difference between reproduction and adaptation might have been significant.

28. See 17 U.S.C. $\S 106$ A(a) (providing certain authors with a right to control the attribution and physical integrity of their work in specific circumstances).

29. See id. §512(f) (prescribing liability for any person who makes a knowing and material misrepresentation as to whether an activity is infringing or was mistakenly disabled or removed).

30. See id. § 1201(a)-(b) (establishing primary and secondary liability for the circumvention of certain technological measures protecting copyrighted works).

31. See id. $\S 1202$ (a) (prohibiting the knowing and intentional provision or distribution of false copyright management information). 
federal and state law claims alleging any likelihood of confusion or passing off), (2) breach of contract, and (3) other causes of action.

We then divided all the cases into three broad categories. We coded cases that alleged infringement via file sharing, filed by either the record or movie industry, as "File Sharing" cases. We coded cases alleging publicperformance infringement of musical works (usually by food and drink establishments) as "Performing Rights" suits-so called because a performing rights organization like ASCAP or BMI was evidently behind the suit, even if not as a named plaintiff. We identified these two categories specifically because of their abundance during the years investigated (particularly the File Sharing suits) ${ }^{32}$ and the observed uniformity of the complaints in these types of suits. The final category - cases that did not fall into either of the other two categories - we called "Commonplace" suits.

Finally, we used the complaint to identify the remedies sought by the plaintiff. For monetary relief, we coded for both actual damages and statutory damages. ${ }^{33}$ We also coded for whether the complaint requested an injunction. Any requests for remedies not related to copyright claims were ignored.

\section{B. The Docket}

Having finished with the complaint, we turned to the case's docket, and the other filings it contained, to collect more information on the litigation.

We first examined the docket to determine whether any defendant filed an answer, a counterclaim, or a cross-claim. We also identified cases that were consolidated or transferred, or whose filing was the result of consolidation or transferring. ${ }^{34}$

We next identified all dispositive motions filed by either party. For example, we coded whether a party filed a motion for summary judgment ${ }^{35}$ or motion for dismissal ${ }^{36}$ under the Federal Rules of Civil Procedure. We also noted the number of substantive decisions made by the court-any

32. See Sarah McBride \& Ethan Smith, Music Industry to Abandon Mass Suits, WALL ST. J., Dec. 19, 2008, http://online.wsj.com/news/articles/SB122966038836021137 (noting that from 2003 through 2008 the recording industry had sued about 35,000 people).

33. See 17 U.S.C. $§ 504(\mathrm{c})(1)$ (specifying that the copyright owner may elect to be awarded statutory damages up to $\$ 30,000$ instead of actual damages and profits). We coded statutory damages only if the complaint specifically asked for such relief. In such cases we also accounted for whether the plaintiff sought enhanced damages for willfulness or reduced damages for innocent infringement. See id. §504(c)(2) (providing for increased statutory damages up to $\$ 150,000$ in the case of willful infringement or reduced statutory damages "not less than $\$ 200$ " if the infringer was unaware and had no reason to believe his activity amounted to infringement).

34. Both consolidations and transfers were coded simply as "Consolidation."

35. FED. R. CIV. P. 56(a).

36. FED. R. CIV. P. 12(b)(6). 
order or other decision by the court resolving a dispute between the parties. ${ }^{37}$

We then determined the circumstances surrounding the termination of the suit. ${ }^{38}$ We identified whether the case went to trial, and if so whether certain post-trial motions were filed and granted. The type of termination was also coded, as was the date of ultimate termination of the case. We also noted the winning party, if any.

Finally, the docket and other filings provided insight into whether any copyright remedies were awarded in the case. We coded whether an injunction was issued, even if by agreement of the parties. The specifics of the monetary remedy awarded, if any, were also coded.

\section{Study Results}

This Part sets forth the study's findings with regard to the information extracted from the complaints and dockets - the raw, descriptive data. (For correlations, regressions, and the accompanying analysis, see Part IV.)

We divide this description into two subparts. In subpart III(A) we cover the Commonplace cases and the Performing Rights cases, with a focus on the former, and in subpart III(B) we cover the File Sharing cases. We parse the cases this way because Commonplace and Performing Rights cases are most representative of the day-in, day-out copyright litigation that is the focus of our inquiry. In contrast, the File Sharing cases - although more numerous ${ }^{39}$ - are unique to the time period at issue; the plaintiffs ceased filing most of these suits at the end of 2008, the last year of our study. ${ }^{40}$ Allowing the unique, fleeting File Sharing litigation campaign to dominate the analysis would result in a distorted view of everyday, copyright litigation.

37. This was interpreted broadly to capture any instance in which a judge or magistrate judge issued an order that resolved a dispute between the parties or ruled on a motion in which the court had to take on the role of an absent party (e.g., a default judgment motion).

38. Of the 957 copyright cases ultimately coded, only 14 were still open at the time of coding. We coded the ultimate termination of the case rather than any earlier termination of a particular party.

39. The File Sharing cases constituted just over half $(53.5 \%)$ of the total number of coded cases.

40. See McBride \& Smith, supra note 32 (reporting on copyright owners' new initiative to fight file-sharing by working with Internet service providers rather than suing individuals). One might wonder why we studied a time period that included this particularly one-off, unrepresentative litigation campaign. As mentioned earlier, see supra note 13, we wanted to cover as recent a time period as possible, yet still study several years' worth of cases that had already terminated. With those goals in mind, choosing a time period that included the File Sharing cases was unavoidable. 


\section{A. Commonplace and Performing Rights Cases}

Although we group the Commonplace and Performing Rights cases together in this subpart, we will focus mostly on the former for two reasons. First, there are 383 Commonplace cases in our sample, versus only 62 Performing Rights cases. Second, the Performing Rights cases are very homogenous and thus can be easily described: they are filed by the owners of copyrights in musical works (mostly subsidiaries of Fortune 1000 companies), the defendants are almost always small food-and-drink establishments and their owners, the claims comprise unauthorized public performance and secondary infringement, and the cases do not go to trial (with only one exception). We will therefore use the footnotes to identify any other material or unexpected differences in the Performing Rights cases.

\section{Complaint Content.}

a. Party Characteristics. - We begin with a description of the parties involved in Commonplace copyright cases.

In terms of sheer numbers, we found that plaintiffs tend to fly solo, but defendants are sued in small groups. Table 1 sets forth those findings.

Table 1: Number of Parties

\section{Commonplace Cases $(n=383)$}

\begin{tabular}{|l|c|c|c|c|}
\hline & Mean & Median & Std. Dev. & Range \\
\hline Plaintiffs & 1.70 & 1.0 & 3.85 & $1-71$ \\
\hline Non-Doe Defendants & 3.26 & 2.0 & 3.70 & $0-37$ \\
\hline All Defendants & 16.34 & 3.0 & 115.17 & $1-2002$ \\
\hline
\end{tabular}

As one can see, the average number of plaintiffs was $1.70 .^{41}$ The median number of plaintiffs was 1 -meaning that more than half the cases involved only a single plaintiff. ${ }^{42}$ The highest number of plaintiffs in a single suit was 71 , but the second highest was 15 , and only four cases had more than 10 .

Counting defendants was more complicated, because a few plaintiffs sued a high number of Doe defendants (up to 2,000!) in addition to named defendants. Even without the Does, however, defendants tended to

41. At a $95 \%$ confidence level, the margin of error is \pm 0.39 .

42. This was not true of the Performing Rights cases, where the average number of plaintiffs was 8.52. Combining Commonplace and Performing Rights plaintiffs would produce a mean of 2.66 . 
outnumber plaintiffs: a mean of 3.26 non-Doe defendants, with a median of $2 .^{43}$

Next, the size of the parties. As already mentioned, this field had three categories: Fortune 1000 companies (and their subsidiaries), individuals (including Does), and small firms (i.e., any party that did not fall into one of the other two categories). As Table 2 shows, small firms dominated as plaintiffs, constituting the largest plaintiff in $64.23 \%$ of cases. Individuals accounted for $21.41 \%$ of the remainder and Fortune 1000 companies and their subsidiaries made up only $14.36 \%{ }^{44}$ (We also found that the author of the copyrighted work was a plaintiff in the vast majority of cases$81.72 \%$ - suggesting a lack of a widespread "copyright troll" problem.)

Table 2: Size of Parties

\section{Commonplace Cases $(n=383)$}

\begin{tabular}{|l|c|c|c|}
\hline & Fortune 1000 & Small Firm & Individual \\
\hline Largest Plaintiff & $14.36 \%$ & $64.23 \%$ & $21.41 \%$ \\
\hline Largest Defendant & $14.62 \%$ & $72.06 \%$ & $13.32 \%$ \\
\hline
\end{tabular}

On the defendant side of the caption, smaller firms dominated even more than they did as plaintiffs; they constituted the largest defendant $72.06 \%$ of the time. Fortune 1000 companies were a distant second, at $14.62 \%$ (which means they tend to be sued as often as they sue). ${ }^{45}$ Individuals placed third, at $13.32 \%$, even though Doe defendants were coded as individuals. ${ }^{46}$

Finally, what industries are involved in copyright litigation? Table 3 provides the answer on the plaintiff side. These data convey two immediate impressions. The first is that no one industry dominated; the most litigious industry was Apparel/Fashion/Textiles, clocking in at $13.58 \%$. Indeed,

43. At a $95 \%$ confidence level, the margin of error is \pm 0.37 . The high number of Does seemed to result from the fact that many plaintiffs sued a manufacturer of allegedly infringing goods and then also named several Doe distributors, or vice versa.

44. In contrast to the Commonplace cases, the Performing Rights cases almost always involved a Fortune 1000 company or subsidiary as plaintiff $(96.77 \%)$, with the small remainder comprising small firms. On the other side of the caption, $85.48 \%$ of Performing Rights defendants were small firms and the rest were individuals.

45. At a $95 \%$ confidence level, the margin of error for Fortune 1000 firms as plaintiffs in Commonplace cases is $\pm 3.47 \%$ and as defendants it's $\pm 3.50 \%$. This means we are $95 \%$ confident that Fortune 1000 firms are plaintiffs in $10.89 \%$ to $17.83 \%$ of cases and defendants in $11.12 \%$ to $18.12 \%$. Thus, they tend to be sued as often as they sue.

46. Coding all Doe defendants as individuals probably resulted in some overcounting of the Individual category and undercounting of the Small Firm category, as there were a few Doe defendants who were alleged to be businesses. 
each industry was within the margin of error of at least one other industry, as Chart 1 illustrates. ${ }^{47}$

\section{Table 3: Industry of the Largest Plaintiff Commonplace Cases $(n=383)$}

\begin{tabular}{|l|c|}
\hline Apparel/Fashion/Textiles & $13.58 \%$ \\
\hline Software-Other & $12.79 \%$ \\
\hline Music & $10.18 \%$ \\
\hline Film and TV & $9.40 \%$ \\
\hline Publishing & $9.40 \%$ \\
\hline Architecture & $9.14 \%$ \\
\hline Commercial Arts & $7.83 \%$ \\
\hline Industrial Design & $7.31 \%$ \\
\hline Other-Misc. & $5.74 \%$ \\
\hline Other-Professional/Scientific/Technical & $5.22 \%$ \\
\hline Other-Retail/Wholesale/Durable Goods & $3.13 \%$ \\
\hline Advertising and Marketing & $2.09 \%$ \\
\hline Fine Arts & $1.57 \%$ \\
\hline Individual & $0.78 \%$ \\
\hline Performing Arts & $0.78 \%$ \\
\hline Software-Video Games & $0.78 \%$ \\
\hline Public Sector & $0.26 \%$ \\
\hline
\end{tabular}

47. This is partly a function of the variety of different industries represented in the coding; with seventeen categories, it is not surprising to see some clustering. But as discussion of Core and Non-Core industries in Part IV will show, there is significant clustering even when industries are aggregated into two broad categories. 


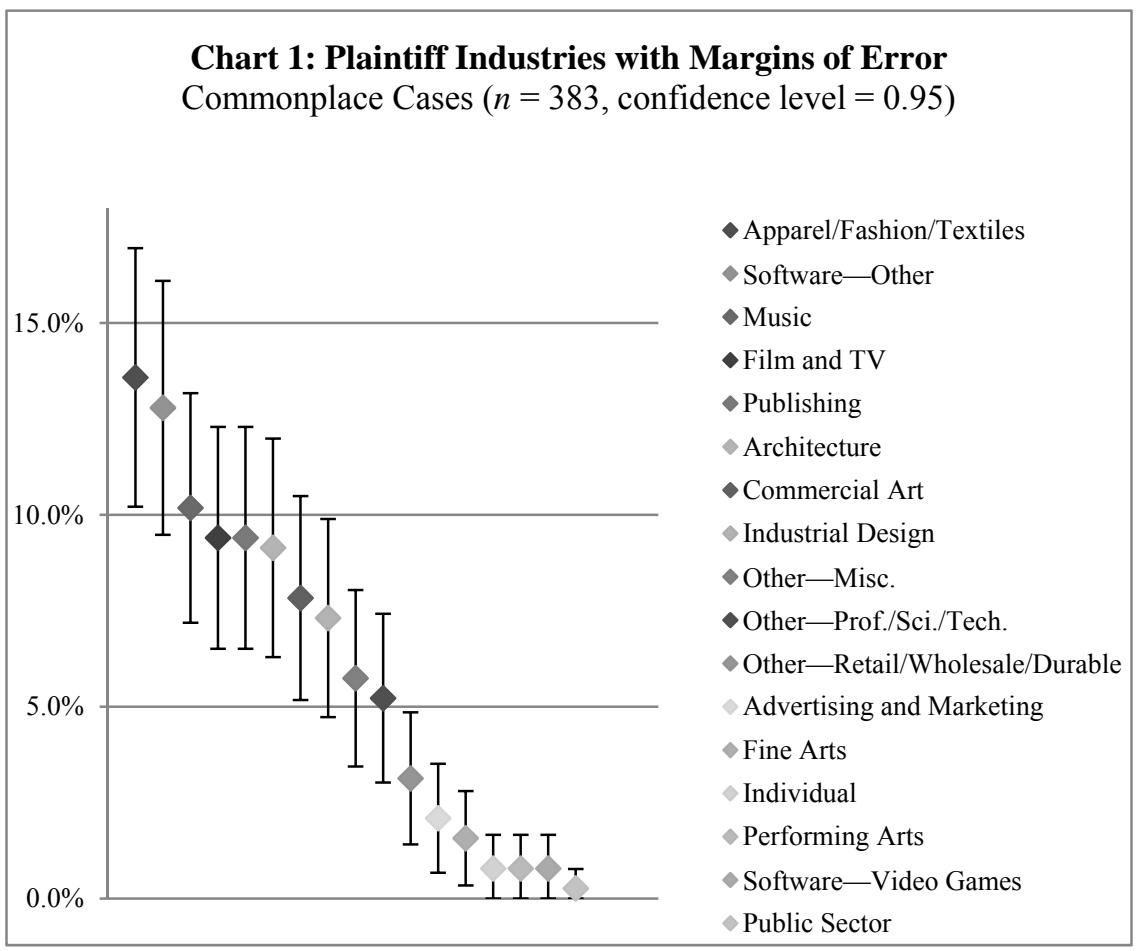

The second impression is that although the industries high on the list include some of copyright's usual suspects, such as software and music, several others are "low-IP" industries - e.g., Architecture, Industrial Design — including the industry atop the list, Apparel/Fashion/Textiles. We will explore this point further below, in subpart IV(B).

Similar results are obtained when one examines the industry of the largest defendant, as displayed in Table 4. Once again we see Apparel/Fashion/Textiles occupying the top spot, with a mix of high-IP and low-IP industries close behind. We also see another significant clustering of industries, as Chart 2 shows. 


\section{Table 4: Industry of the Largest Defendant Commonplace Cases $(n=383)$}

\begin{tabular}{|l|c|}
\hline Apparel/Fashion/Textiles & $13.58 \%$ \\
\hline Software-Other & $11.75 \%$ \\
\hline Music & $8.09 \%$ \\
\hline Film and TV & $8.62 \%$ \\
\hline Publishing & $9.40 \%$ \\
\hline Architecture & $9.14 \%$ \\
\hline Commercial Arts & $3.39 \%$ \\
\hline Industrial Design & $6.01 \%$ \\
\hline Other-Misc. & $7.05 \%$ \\
\hline Other-Professional/Scientific/Technical & $6.79 \%$ \\
\hline Other-Retail/Wholesale/Durable Goods & $8.88 \%$ \\
\hline Advertising and Marketing & $2.09 \%$ \\
\hline Fine Arts & $0.78 \%$ \\
\hline Individual & $2.09 \%$ \\
\hline Performing Arts & $0.78 \%$ \\
\hline Software-Video Games & $0.78 \%$ \\
\hline Public Sector & $0.78 \%$ \\
\hline
\end{tabular}

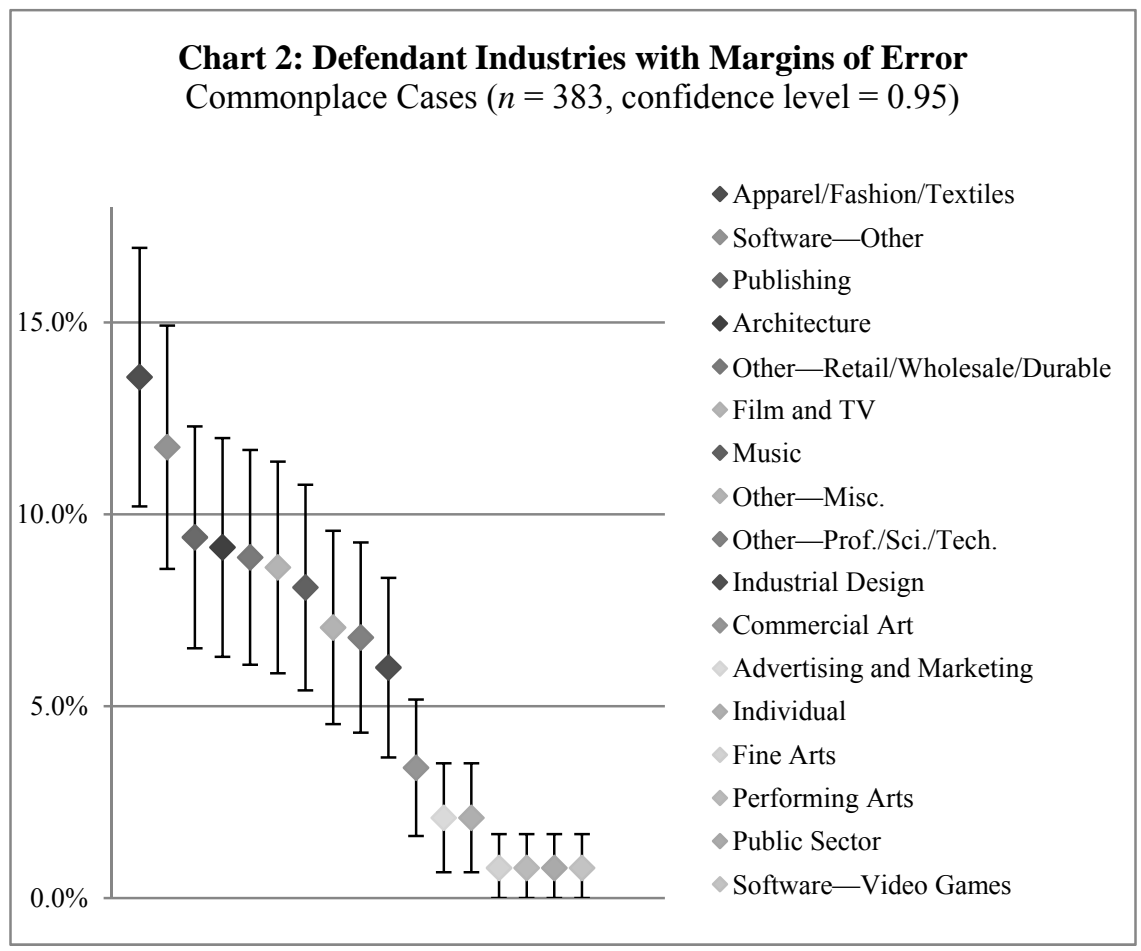


b. Nature of Disputes.-We now turn to the subject matter at issue and the claims found in the Commonplace complaints. We begin with Table 5, which reports on subject matter - the kinds of work that were the subject of the lawsuits.

As with the industry data, we see some usual suspects sharing top billing with some surprising companions. Three of the six most litigated kinds of works were low-IP: Apparel/Fashion/Textiles, Architectural Works, and Industrial Design. Together these three categories made up almost $30 \%$ of all litigated works. (A low-IP theme is clearly emerging from the data - a theme to which we will return in subpart IV(B).)

\section{Table 5: Subject Matter-Specific Categories} Commonplace Cases $(n=383)$

\begin{tabular}{|l|c|}
\hline Literary Work-Software & $13.05 \%$ \\
\hline PGS Work-Commercial Art & $12.27 \%$ \\
\hline PGS Work-Apparel/Fashion/Textiles & $12.01 \%$ \\
\hline Motion Picture or Other Audiovisual Work & $9.40 \%$ \\
\hline Architectural Work & $8.88 \%$ \\
\hline PGS Work-Industrial Design & $8.36 \%$ \\
\hline Literary Work-Books/Newspapers/Journals & $8.09 \%$ \\
\hline Literary Work-Industry Publications & $7.05 \%$ \\
\hline Musical Work (“MW”) & $7.05 \%$ \\
\hline Multiple-Website & $5.48 \%$ \\
\hline Literary Work-Other & $2.09 \%$ \\
\hline Multiple-MW and SR & $1.83 \%$ \\
\hline PGS Work-Fine Art & $1.57 \%$ \\
\hline Sound Recording (“SR”) & $1.04 \%$ \\
\hline Dramatic Work & $0.78 \%$ \\
\hline Multiple-Other & $0.78 \%$ \\
\hline Pantomimes or Choreographic Work & $0.26 \%$ \\
\hline
\end{tabular}

Table 6 shows the number of works that were the subject of the suits. The average is 21.26 , but that number is not particularly meaningful because a handful of cases claimed infringement of hundreds - or, in one case, thousands - of works, and they distort the average. (Thus the large standard deviation.) More significant is the median, which is 2.0, indicating that more than half the cases involved multiple works. This finding may have implications for the portfolio theory of intellectual property, under 
which firms own and exploit a collection of works whose aggregate value exceeds the sum of their individual values. ${ }^{48}$

Table 6: Number of Works

\section{Commonplace Cases $(n=383)$}

\begin{tabular}{|c|c|c|c|}
\hline Mean & Median & Std. Dev. & Range \\
\hline 21.26 & 2.0 & 197.33 & $1-3737$ \\
\hline
\end{tabular}

Next we examine the types of claims that plaintiffs make in Commonplace cases. As we see in Table 7, the vast majority of cases (95.04\%) involved claims of federal copyright infringement, with no other copyright claim. State infringement claims accompanied federal claims in less than $2 \%$ of cases, and state infringement claims stood on their own even more rarely-roughly 1 in every 400 cases. In $2.87 \%$ of cases, however, there was no infringement claim at all; instead, in these "quiet title" cases, the plaintiff merely asked the court to resolve a copyright ownership dispute.

Table 7: Types of Claims-Federal, State, and Foreign Commonplace Cases $(n=383)$

\begin{tabular}{|c|c|c|}
\hline \multirow{4}{*}{$\begin{array}{c}\text { Federal and State } \\
\text { Claims }\end{array}$} & Federal Infringement & $95.04 \%$ \\
\cline { 2 - 3 } & State Infringement & $1.83 \%$ \\
\cline { 2 - 3 } & $\begin{array}{c}\text { Federal and State } \\
\text { Infringement }\end{array}$ & $0.26 \%$ \\
\cline { 2 - 3 } & Ownership Dispute Only & $2.87 \%$ \\
\hline \multirow{2}{*}{ Foreign Claims } & Infringement Only & $2.61 \%$ \\
\cline { 2 - 3 } & Moral Rights Only & $0.00 \%$ \\
\cline { 2 - 3 } & Infringement and Moral Rights & $0.26 \%$ \\
\hline
\end{tabular}

Foreign claims - claims of copyright violation under foreign law, or claims based on works that originated abroad-were uncommon as well. Infringement claims of this type occurred on their own in $2.61 \%$ of cases, and in an additional $0.26 \%$ of cases when combined with a foreign moral rights claim.

Table 8 divides federal infringement claims into the $\S 106$ subsection on which they are based. ${ }^{49}$ The most frequent claims involved unauthorized

48. Gideon Parchomovsky \& R. Polk Wagner, Patent Portfolios, 154 U. PA. L. REV. 1, 5-6 (2005).

49. See 17 U.S.C. $§ 106$ (2012) (delineating the rights of copyright owners). 
reproduction of the work under $\S 106(1)$; such claims occurred in $87.99 \%$ of cases. Unauthorized distribution was close behind, at $73.89 \%$. Unauthorized adaptation - the making of derivative works - was a distant third, at $36.81 \%$. Public Display came next, at $22.45 \%$, with traditional Public Performance at $9.40 \%$ and public performance of sound recordings by means of digital audio transmission at $0.26 \%$ (representing just 1 case out of 383 ).

Table 8: Types of Claims-Copyright Act

Commonplace Cases $(n=383)$

\begin{tabular}{|c|c|c|}
\hline \multirow{6}{*}{$\begin{array}{l}17 \text { U.S.C. § } 106 \\
\text { Claims }\end{array}$} & $\begin{array}{l}\text { Section 106(1): } \\
\text { Reproduction }\end{array}$ & $87.99 \%$ \\
\hline & $\begin{array}{c}\text { Section } 106(2) \text { : } \\
\text { Adaptation }\end{array}$ & $36.81 \%$ \\
\hline & $\begin{array}{l}\text { Section 106(3): } \\
\text { Distribution }\end{array}$ & $73.89 \%$ \\
\hline & $\begin{array}{c}\text { Section 106(4): } \\
\text { Public Performance }\end{array}$ & $9.40 \%$ \\
\hline & $\begin{array}{l}\text { Section 106(5): } \\
\text { Public Display }\end{array}$ & $22.45 \%$ \\
\hline & $\begin{array}{l}\text { Section 106(6): } \\
\text { Digital Audio Transmission }\end{array}$ & $0.26 \%$ \\
\hline \multirow{3}{*}{$\begin{array}{l}\text { Other Copyright } \\
\text { Claims }\end{array}$} & Secondary Liability & $26.63 \%$ \\
\hline & $\begin{array}{c}\text { VARA } \\
\text { (Section 106A) }\end{array}$ & $1.31 \%$ \\
\hline & $\begin{array}{c}\text { DMCA } \\
\text { (Sections 512, 1201 \& 1202) }\end{array}$ & $4.70 \%$ \\
\hline
\end{tabular}

Shifting to claims outside of $\S 106$, we found allegations of secondary liability to be fairly common, occurring $26.63 \%$ of the time. In contrast, DMCA claims were rare (4.70\%) and VARA claims even more so $(1.31 \%)$.

The other category of claims we coded were non-copyright claims that accompanied the copyright claims, as we see in Table 9. Trademark claims were a frequent companion, occurring in $35.25 \%$ of Commonplace cases. Breach of contract was a fellow traveler in approximately 1 in every 5 suits. And other kinds of claims - a mix of trade secret, fiduciary duty, conversion, and more - occurred $48.04 \%$ of the time. All in all, plaintiffs filed a non-copyright claim of one kind or another in $61.62 \%$ of all cases. 
Table 9: Type of Claims Non-Copyright Commonplace Cases $(n=383)$

\begin{tabular}{|l|l|}
\hline Trademark & $35.25 \%$ \\
\hline Breach of Contract & $20.10 \%$ \\
\hline Other & $48.04 \%$ \\
\hline Any Additional Claim & $61.62 \%$ \\
\hline
\end{tabular}

Finally, we examined the complaints to see what remedies plaintiffs sought. Statutory damages are usually considered an important weapon in a copyright owner's arsenal, ${ }^{50}$ and the numbers in Table 10 bear this out. Enhanced statutory damages claims for willful infringement (maximum $\$ 150,000$ per work infringed) $)^{51}$ were far and away the most common monetary remedy that the complaints requested, surfacing in $69.71 \%$ of Commonplace cases. ${ }^{52}$

Table 10: Types of Damages Non-Copyright Commonplace Cases $(n=383)$

\begin{tabular}{|c|l|c|}
\hline \multirow{4}{*}{ Damages } & $\begin{array}{l}\text { Statutory Damages- } \\
\text { Enhanced }\end{array}$ & $69.71 \%$ \\
\cline { 2 - 3 } & Actual Damages & $18.54 \%$ \\
\cline { 2 - 3 } & $\begin{array}{l}\text { Statutory Damages- } \\
\text { Unenhanced }\end{array}$ & $5.48 \%$ \\
\cline { 2 - 3 } & None & $6.27 \%$ \\
\hline \multicolumn{2}{|c|}{ Injunction Pleaded } & $96.34 \%$ \\
\hline
\end{tabular}

Actual damages were a distant second to enhanced statutory damages, at $18.54 \%$, with unenhanced statutory damages third at $5.48 \%$. (In the remaining $6.27 \%$ of cases, plaintiffs sought no damages at all.) But the most common remedy that plaintiffs pleaded was an injunction, seen in $96.34 \%$ of cases.

c. Courts. - The last data we collected from the complaints had to do with the courts in which plaintiffs chose to file their cases. The Central District of California, home to Hollywood, dominated the Commonplace

50. See Pamela Samuelson \& Tara Wheatland, Statutory Damages in Copyright Law: A Remedy in Need of Reform, 51 WM. \& MARY L. REV. 439, 442-43 (2009) (providing examples of "grossly excessive" statutory damages awards and discussing the "chilling effect" they produce).

51. 17 U.S.C. $\S 504(c)(2)$.

52. Note that the Performing Rights plaintiffs uniformly asked for statutory damages, but never alleged enhanced damages based on willfulness. This is in contrast to the File Sharing plaintiffs, who always sought the full $\$ 150,000$ per work. 
category, with $18.54 \%$ of filings. The Southern District of New York was next, with $11.75 \%$. No other district was above the $4 \%$ mark. $^{53}$ Grouping the district courts by federal circuit produced similar results, with the Ninth Circuit leading the way $(32.38 \%)$ followed by the Second $(16.71 \%)$. Only one other circuit was above ten percent - the Eleventh, at 10.18\%.

2. Course of Litigation.-Having finished with the complaint, we now turn to the remainder of the docket to glean information regarding the course of copyright litigation.

a. Defendant's Response.-The first focus is on the defendant's answer, or lack thereof. Defendants answered in slightly over half of the 383 Commonplace cases $(57.70 \%-221$ cases $)$, to be exact. Of these 221 cases, only $23.24 \%$ (89) also included counterclaims or cross-claims. And for the 162 cases with no answer filed, we observed a dispositive motion (other than a motion for default judgment by the plaintiff) in only 33 cases. This leaves 33.68\% (129 cases) of the Commonplace cases with no responsive action by the defendant except, possibly, consenting to a judgment or settlement. ${ }^{54}$

b. Activity During the Case's Pendency.-As the Commonplace cases moved toward termination, only $3.92 \%$ were consolidated or transferred. And at least one party filed a dispositive motion - a motion that if successful would have terminated one or more copyright claims$45.93 \%$ of the time. The specific breakdown of the dispositive motions observed is set forth in Table 11.

53. The 62 Performing Rights cases are much more evenly distributed among courts, with only the Northern District of California having a percentage in the double digits $(11.29 \%)$ and only twelve districts having more than 1 case.

54. As for the Performing Rights cases, we saw answers filed $51.61 \%$ of the time. If there was no answer, there was also no other motion filed by the defendant, with only one exception. The rate at which defendants failed to respond in Performing Rights cases was accordingly much higher than in Commonplace cases. 


\section{Table 11: Dispositive Motions Filed Commonplace Cases $(n=383)$}

\begin{tabular}{|l|c|}
\hline 12(b)(6) Motion & $6.8 \%$ \\
\hline Default Judgment & $6.5 \%$ \\
\hline Summary Judgment & $5.5 \%$ \\
\hline TRO/Preliminary Injunction & $3.9 \%$ \\
\hline Lack of Jurisdiction & $3.1 \%$ \\
\hline Other Dismissal & $1.8 \%$ \\
\hline 12(c) Motion & $0.3 \%$ \\
\hline JNOV & $0.0 \%$ \\
\hline Multiple Motions & $18.02 \%$ \\
\hline None & $54.05 \%$ \\
\hline
\end{tabular}

Notably, in over half of the cases, neither party filed a single dispositive motion, indicating a lack of intensity in the litigation. Once a dispositive motion was filed, however, more would usually follow, as Multiple is the second-highest score on the list $-18.02 \%$, representing 69 cases.

Nor did many cases terminate through a district court's decision on a dispositive motion. Of the 377 Commonplace cases that had terminated at the time of our study, only $10.96 \%$ terminated on summary judgment, under Rules 12(b)(6) or 12(c), on a motion for default judgment, or for lack of jurisdiction. Most cases $(88.86 \%)$ terminated voluntarily. ${ }^{55}$

Two other measures of a case's intensity-how hard the parties fought - are the number of substantive, contested decisions made by the court and, to a lesser extent, the number of docket entries in a case. Both of these were observed to be quite low.

In the Commonplace cases, the median number of substantive, contested decisions made was 1 . The number of such decisions ranged widely, from 0 to 117 , with the mean being 2.35 and the standard deviation being 7.10. Just under half the Commonplace cases (49.35\%) contained no substantive decisions, and $70.50 \%$ contained 1 or fewer.

The median number of docket entries for the Commonplace cases was 29 , with the average number of docket entries being 52.11 with a standard deviation of 85.78. The number of docket entries ranged from 2 to 1,085.

Finally, very few Commonplace cases $(4.24 \%$ - 16 cases $)$ went to trial. Post-jury verdict motions (judgments notwithstanding verdict or judgments as a matter of law) were filed in 6 of those cases, but the court denied them all. $^{56}$

55. For more on this data, see infra Table 12.

56. The Performing Rights cases had less activity across the board. The only dispositive 
c. Termination.-The data also show how copyright cases terminate. First, who won? In an overwhelming majority of Commonplace cases $(85.41 \%)$ the case was dismissed with neither party winning an adversarial judgment over the other (although roughly 1 in 5 of those cases involved a consent judgment filed with the court). Of the $16.18 \%$ of cases in which there was an explicit winning party, the defendant won a little more than half $(54.10 \%)$ and the plaintiff a little less $(45.90 \%){ }^{57}$

Table 12: Termination Type Commonplace Cases $(n=383)$

\begin{tabular}{|l|c|}
\hline Voluntary Dismissal & $34.46 \%$ \\
\hline Settlement & $29.50 \%$ \\
\hline Agreed Judgment & $16.19 \%$ \\
\hline Default Judgment & $5.48 \%$ \\
\hline Other Dismissal & $4.44 \%$ \\
\hline Trial & $2.87 \%$ \\
\hline 12(b)(6) Dismissal & $2.35 \%$ \\
\hline Summary Judgment & $2.09 \%$ \\
\hline Still Open & $1.57 \%$ \\
\hline 12(c) Dismissal & $0.52 \%$ \\
\hline Lack of Jurisdiction & $0.52 \%$ \\
\hline JNOV & $0.00 \%$ \\
\hline
\end{tabular}

As to how the cases terminated, most of the cases $(80.16 \%)$ terminated voluntarily through a settlement, agreed judgment, or voluntary dismissal. In contrast, very few terminated via trial $(2.87 \%)$ or by dispositive motion $(10.97 \%)$. The specific breakdown of termination is set forth in Table $12 .{ }^{58}$

Most cases took around a year to reach termination. Of the 377 Commonplace cases that reached termination, the median time to termination was 288 days, while the mean time to termination was 413.06 days with a standard deviation of 410.35 . The range was 11 days to 2,548

motion filed in most Performing Rights cases was for default judgment $-20.10 \%$ of the time, representing 13 cases; in only 6 additional cases was any other dispositive motion filed, leaving $69.35 \%$ of the cases with no dispositive motion at all. Accordingly, the number of substantive decisions stayed extremely low, with $62.9 \%$ of cases having no substantive decisions and $90.32 \%$ having 1 or fewer. Only 1 Performing Rights case went to trial.

57. As for the Performing Rights cases, the winning party breakdown is similar to the Commonplace cases, with $72.58 \%$ of the cases resulting either in a win for neither party or in an agreed judgment. One deviation from the Commonplace cases, however, is that no defendant ever won a Performing Rights case outright.

58. The terminations in Performing Rights cases were largely voluntary $(70.97 \%)$ or default judgments (17.74\%). 
days. Half of the cases pended for a year or less and $84.08 \%$ pended for less than two years. ${ }^{59}$

d. Remedies Granted.-For those Commonplace cases that did terminate, an overwhelming number resulted in no remedies granted by the court, which is not surprising given that most terminated through action of the parties rather than the court. Only $23.61 \%$ saw damages or an injunction granted. And if the agreed-judgment cases are removed, the number drops even further to $8.49 \%$.

The court granted an injunction in $22.02 \%$ (83) of the cases. Of these injunctions, the vast majority (53 of 83 cases) were the result of an agreed judgment between the parties. As for monetary damages, the distribution is shown in Table 13.

Table 13: Awarded Damages Commonplace Terminated Cases $(n=377)$

\begin{tabular}{|l|c|}
\hline Statutory-Willful & $1.59 \%$ \\
\hline Statutory-Regular & $4.24 \%$ \\
\hline Statutory-Innocent & $0 \%$ \\
\hline Actual Damages & $1.59 \%$ \\
\hline$>0$ but can't tell more & $0.27 \%$ \\
\hline Agreed Damages & $6.37 \%$ \\
\hline None & $87.53 \%$ \\
\hline
\end{tabular}

In the $14.06 \%$ of cases awarding damages, most were either regular statutory damages or agreed damage awards in consent judgments. Taking away the agreed awards, the percentage of cases resulting in damages drops to $7.69 \%$, with regular statutory damages dominating the outcomes. ${ }^{60}$

59. The Performing Rights cases are similar to the Commonplace cases with regard to time to termination, with a median of 308 days and a mean of 429.87 . The standard deviation, however, is much lower (425.08 days) which is not surprising given that most Performing Rights cases terminated the same way, within the same time frame.

60. The Performing Rights cases saw a higher incidence of remedy awards. Of the 61 cases that terminated, injunctions were issued in $21(34.43 \%)$. The figure drops to $24.59 \%(15)$ of the cases if agreed injunctions are removed. As for damage awards, they appear in $42.62 \%$ (26) of the cases, and they drop to $24.59 \%$ (15) if one does not count agreed damages. 


\section{B. File Sharing Cases}

1. Complaint Content.-We need not spend much time on the content of the complaints in the File Sharing cases, as they were all based on the same template and therefore differed from one another in only a few ways.

Of the 512 File Sharing cases, 93.75\% were filed by the recording industry, with an average of 5.8 labels joining together as plaintiffs. The remaining cases were brought by the movie and television industry, with an average of 2.6 studios as plaintiffs. Most of the cases $(70.51 \%)$ involved a single, named individual as defendant, but a sizeable minority $(29.49 \%)$ were Doe-defendant cases. The latter tended to involve multiple defendants (5.8 on average) and were filed so that the plaintiffs could issue subpoenas to Internet service providers, so as to discover the identity of the Does using their IP addresses. The recording industry cases averaged 8.4 works per defendant (all sound recordings), with the movie industry cases at 2.1 (all audiovisual works).

Other than that, the complaints were essentially identical. The largest plaintiff was always a Fortune 1000 firm or subsidiary. The claims were exclusively federal copyright infringement and only claimed violations of the right to reproduce and the right to distribute. In all instances, the plaintiffs sought injunctions and statutory damages based on willful infringement.

The only other data of note involved the courts in which the cases were filed. Here we observed some surprising contrasts with the non-File Sharing cases. The only district with more than $10 \%$ of the File Sharing cases was the Eastern District of Pennsylvania, with $15.43 \%$. The Western District of Texas was next, with $8.60 \%$. The only other two jurisdictions with more than $5 \%$ were the Southern District of Texas, with $6.05 \%$, and the Northern District of Illinois, with $5.07 \%$. The two courts that dominated the Commonplace cases - the Central District of California and the Southern District of New York-were sixth, with $4.10 \%$, and ninth, with $2.54 \%$, on the File Sharing list, respectively, making each about threequarters smaller in representation than in the Commonplace cases.

2. Course of Litigation.-For the File Sharing cases, the most interesting non-complaint data came from the non-Doe cases, of which there were 361 , because very few Doe cases proceeded much further past the complaint. ${ }^{61}$

In the non-Doe cases, the defendant answered the complaint only $11.13 \%$ of the time, a much lower percentage than that observed in non-File Sharing cases. (Even the Performing Rights cases had a higher answer rate

61. No answers were filed in any of the Doe cases and very few, if any, dispositive motions were filed or terminations occurred (other than voluntary dismissals). 
of 51.6\%.) And when the defendant filed no answer, he or she also filed no dispositive motion. Indeed, named defendants did not file any motions in the File Sharing cases; the dispositive motion practice was left to plaintiffs filing for default judgments, which occurred in $38.50 \%$ of the cases.

Given this low defendant response rate, it is no surprise that the overall activity in the cases was minimal. In $95.29 \%$ (344) of the non-Doe cases, the court made fewer than two substantive decisions. And in 55.68\% (201) of those cases, not a single substantive decision was made. The highest number of substantive decisions in any File Sharing case was eleven.

Most of the non-Doe cases $(63.43 \%)$ ended in a voluntary termination of some sort. In the remainder, the plaintiff was declared the winner, mostly by default judgment. Just as with the Performing Rights cases, no File Sharing case ended with the court identifying the defendant as the winning party. And the time to get to these terminations was shorter than in Commonplace cases, with a median of about half a year (185 days) and a mean of 286.50 days with a standard deviation of 316.81 .

As for remedies, the court explicitly ordered damages in $33.52 \%$ of the 361 non-Doe cases, with the plaintiff getting unenhanced statutory damages in 117 of those cases (32.4\%) and an injunction in 120 (33.24\%).

\section{Analysis}

We hope the foregoing description of our data will be of help to legislators, practitioners, scholars, and others interested in the practice and development of copyright law. In the last Part of this Article, however, we move from description to analysis, using correlations and regressions to delve more deeply into the data. Or at least some of it. Given the sheer breadth of the information collected, we have chosen only two issues to explore. (We leave other avenues of inquiry to future researchers, to whom we gladly make our data available. ${ }^{62}$ ) First we will examine the differences between copyright litigation and other civil cases. Then we will explore the ways in which the identities of the parties and subject matters in copyright cases interact with one another-and sometimes influence litigation outcomes.

\section{A. Comparing Copyright Cases to Other Civil Litigation}

In this subpart, we compare our copyright case data to various data sets involving other kinds of civil litigation, in an attempt to see whether copyright litigation is unique. In particular, we examine where cases are filed, the extent to which cases are "hard," and how and when they terminate.

62. COPYright L. DATA: COPYRight Litig. DAta Project, http://www.copyrightlaw data.com. 
Our analysis confirms the commonly accepted belief that copyright cases are filed at a higher rate in the Central District of California and Southern District of New York than other civil cases. However, our data indicate that plaintiffs are less likely to receive a favorable judgment in these districts.

We also find, interestingly, that when compared to civil litigation in general and to patent and trademark cases more specifically, copyright cases end up in about the same place - a settlement or voluntary dismissal-but take longer to get there and contain more substantive decisions and docket entries. Copyright cases also result in a higher percentage of trials. All of this suggests that copyright law's complexity, uncertainty, and standard- and fact-driven doctrine cause litigants and courts to work harder to reach the typical civil litigation result. ${ }^{63}$

1. Geographic Distribution of Cases.-The geographic distribution of copyright cases fits with the common notions of copyright "hotbeds." 64 Thirty percent of Commonplace cases were filed in either the Central District of California or Southern District of New York. The question, however, is whether this simply follows the typical distribution of civil litigation in federal courts or is unique to copyright law.

To answer this question, we compared our data to data from the Administrative Office of the United States Courts (AO) from the same time period. $^{65}$ In Table 14, we compare the percentage of all comparable private

63. See, e.g., Shyamkrishna Balganesh, Essay, Copyright Infringement Markets, 113 ColuM. L. REV. 2277, 2297 (2013) (explaining how difficult the "substantial similarity" standard is to determine for both copyright litigants and the courts); Gibson, supra note 11, at 888-89 (describing the inherent malleability and flexibility of the fair use doctrine); id. at 891 (detailing the indeterminacy of other facets of copyright law, such as the "substantial similarity" standard); id. at 905-06 (noting the complex and fact-driven nature of the Supreme Court's copyright holdings).

64. See Michael W. Shiver Jr., Objective Limitations or, How the Vigorous Application of "Strong Form" Idea/Expression Dichotomy Theory in Copyright Preliminary Injunction Hearings Might Just Save the First Amendment, 9 UCLA ENT. L. REV. 361, 370 n.53 (2002) (discussing how the Second and Ninth Circuits have been the hotbeds of copyright litigation for many years, mostly because they contain Hollywood, Silicon Valley, and New York City).

65. We obtained this data from the Inter-university Consortium for Political and Social Research (ICPSR). Specifically, we used the Federal Court Cases: Integrated Data Bases for 2005 through 2011 to garner data on all cases filed from 2005 through 2008. INTER-UNIV. Consortium for Political \& Soc. Research, Fed. Ct. CASES: Integrated Data Base, 2011 (ICPSR 33622), http://doi.org/10.3886/ICPSR33622.v2; INTER-UNIV. CONSORTIUM FOR Politial \& Soc. Research, Fed. CT. CASES: InTEGRATEd DATA BASE, 2010 (ICPSR 30401), http://doi.org/10.3886/ICPSR30401.v2; INTER-UNIV. CONSORTIUM FOR POLITICAL \& SOC. RESEARCH, FED. CT. CASES: INTEGRATED DATA BASE, 2009 (ICPSR 29661), http://doi.org/10.3886/ICPSR29661.v3; INTER-UNIV. CONSORTIUM FOR POLITICAL \& SOC. RESEARCH, FED. CT. CASES: INTEGRATED DATA BASE, 2008 (ICPSR 25002), http://doi.org/10.3886/ICPSR25002.v5; INTER-UNIV. CONSORTIUM FOR POLITICAL \& SOC. RESEARCH, FED. CT. CASES: INTEGRATED DATA BASE, 2007 (ICPSR 22300), http://doi.org/10.3886/ICPSR22300.v3; INTER-UNIV. CONSORTIUM FOR POLITICAL \& SOC. 
civil cases ${ }^{66}$ filed from January 1, 2005 to December 31, 2008, and all patent and trademark cases filed during that time period, in various districts and circuits, using both $\mathrm{AO}$ data and ours.

Table 14: Geographic Distribution Compared

\begin{tabular}{|c|c|c|c|}
\hline & $\begin{array}{c}\text { AO 2005-2008 } \\
\text { Private Civil } \\
\text { Cases } \\
(n=672,728) \\
\end{array}$ & $\begin{array}{c}\text { AO 2005-2008 } \\
\text { Patent and } \\
\text { Trademark Cases } \\
(n=24,796)\end{array}$ & $\begin{array}{c}\text { Commonplace } \\
\text { Copyright } \\
\text { Cases } \\
(n=383) \\
\end{array}$ \\
\hline C.D. Cal. & $\begin{array}{c}3.83 \% \\
(25,823) \\
\end{array}$ & $\begin{array}{r}13.01 \% \\
(3,226) \\
\end{array}$ & $\begin{array}{c}18.54 \% \\
(71) \\
\end{array}$ \\
\hline S.D.N.Y. & $\begin{array}{c}5.85 \% \\
(39,379)\end{array}$ & $\begin{array}{c}6.63 \% \\
(1,645) \\
\end{array}$ & $\begin{array}{c}11.75 \% \\
(45)\end{array}$ \\
\hline S.D. Fl. & $\begin{array}{c}3.14 \% \\
(21,152) \\
\end{array}$ & $\begin{array}{c}3.49 \% \\
(865) \\
\end{array}$ & $\begin{array}{c}2.87 \% \\
(11) \\
\end{array}$ \\
\hline N.D. Ill. & $\begin{array}{c}3.50 \% \\
(23,560) \\
\end{array}$ & $\begin{array}{l}4.57 \% \\
(1,133) \\
\end{array}$ & $\begin{array}{c}2.87 \% \\
(11) \\
\end{array}$ \\
\hline Ninth Circuit & $\begin{array}{l}13.24 \% \\
(89,065) \\
\end{array}$ & $\begin{array}{l}27.84 \% \\
(6,905)\end{array}$ & $\begin{array}{c}32.38 \% \\
(124)\end{array}$ \\
\hline Second Circuit & $\begin{array}{r}10.32 \% \\
(69,452)\end{array}$ & $\begin{array}{l}10.64 \% \\
(2,640)\end{array}$ & $\begin{array}{c}16.71 \% \\
(64)\end{array}$ \\
\hline Fifth Circuit & $\begin{array}{l}13.00 \% \\
(87,470)\end{array}$ & $\begin{array}{l}10.32 \% \\
(2,560)\end{array}$ & $\begin{array}{c}8.88 \% \\
(34)\end{array}$ \\
\hline
\end{tabular}

Looking at Table 14, the difference in distribution between copyright cases and comparable general civil cases is statistically significant. ${ }^{67}$ The

RESEARCH, FED. CT. CASES: INTEgRATED DATA BASE, 2006 (ICPSR 4685), http://doi.org/10.3886/ICPSR04685.v3; INTER-UNIV. CONSORTIUM FOR POLITICAL \& SOC. Research, Fed. CT. CASEs: INTEGRATEd DATA BASE, 2005 (ICPSR 4382), http://doi.org/10.3886/ICPSR04382.v3. The AO collects these data and makes them available through the ICPSR. See Theodore Eisenberg \& Margo Schlanger, The Reliability of the Administrative Office of the U.S. Courts Database: An Initial Empirical Analysis, 78 NOTRE DAME L. REV. 1455, 1456-59 \& n.1 (2003). These data sets are known to have some reliability problems. See, e.g., id. at 1458 (noting that the AO data sets are not completely accurate due to their size and that other researchers have questioned the data sets' reliability); Barton Beebe, An Empirical Study of the Multifactor Tests for Trademark Infringement, 94 CALIF. L. REV. 1581, app. B (2006) (detailing earlier AO data sets' shortcomings and testing their reliability against data collected in trademark infringement cases). Accordingly, we also use other, non-AO data sets for comparison purposes.

66. This included all civil cases in the AO's data set except for habeas cases and all cases in which the United States was a party. We removed these cases in an attempt to construct a more directly comparable general civil litigation data set.

67. Pearson's chi-square reports a $p$-value $<0.0001$. 
consolidation of cases in the Central District of California and Southern District of New York does not follow the typical civil case-filing trends; instead, it is unique to copyright cases. ${ }^{68}$

What makes this observation even more interesting is the identity of the parties litigating in these districts. One might reasonably assume that the plaintiffs are major media companies - content-industry incumbents protecting publications, music, and motion pictures in their own backyards. This assumption is presumably what drives the belief that these are copyright-heavy jurisdictions.

This is, however, not the case. Focusing just on the 71 Commonplace cases filed in the Central District of California, $77.46 \%$ were filed by either individuals or small firms. And the clothing industry made up the highest percentage of plaintiffs in a single industry $(32.40 \%) .{ }^{69}$ Television and motion picture plaintiffs, which one would assume dominate the industry in that district, constituted only $28.16 \%$ of cases filed. Something other than the copyright industries commonly associated with the region is driving litigation in the hot districts. Perhaps the belief that these are copyrightsavvy courts attracts copyright holders of all types to them.

Yet the statistical relationship between various litigation outcomes and the hot districts suggests that those districts are not incredibly plaintiff friendly. We ran a number of regressions and included, as an independent variable, whether a case was filed in either of the two hottest districts, the Central District of California or the Southern District of New York. ${ }^{70}$ That variable significantly predicted only one dependent variable: plaintiff as winning party - and the relationship was negative. ${ }^{71}$ In other words, filing in one of the two hot districts decreased the likelihood of a plaintiff win.

68. Moreover, the Commonplace cases we coded may actually understate the degree of concentration in the Central District of California and Southern District of New York. As detailed earlier, see supra note 16, there were 111 randomly pulled cases in which the electronic version of the complaint was not available. As it turns out, 72 of those cases were filed in the Central District of California and 9 in the Southern District of New York. If the Commonplace cases that appear in these uncoded complaints were included in Table 14, the percentage of copyright cases in these districts would be even higher.

69. Notably, clothing plaintiffs made up the largest percentage of cases filed in the Southern District of New York (22.22\%).

70. All the regressions and their results are reported in Appendix B. In each regression, we controlled for the industry of the parties, the size of the parties, the number of parties, the number of works at issue, whether it was an intra-industry dispute, whether the works were high authorship, whether the author was a plaintiff, and whether the case was filed in one of the two hottest districts.

71. See infra Appendix B, Regressions $1 \& 2$. Both regressions are multinomial logistics with Winning Party as the dependent variable. The only difference between the two is that Regression 1 uses "Plaintiff is a Small Firm" as a binary independent variable and Regression 2 uses "Plaintiff is an Individual" instead. The reasons for running both regressions will become clear in section IV(B)(1), but for present purposes - i.e., measuring the likelihood of a Plaintiff Win in the hot districts - it makes no difference; both produce statistically significant results at a $95 \%$ confidence level, and both report a relative-risk ratio of around 0.34 (meaning that the plaintiff's 
In short, although a disproportionately high number of copyright cases are filed in the Central District of California and Southern District of New York, plaintiffs are less likely to obtain a judgment in their favor there. Of course, these plaintiffs may still be receiving favorable settlements, and there is not a statistically significant relationship between defendant wins and the hot districts. Nevertheless, the data suggest that there is a disconnect between any perception of favorability in these districts and the reality of fewer outright plaintiff victories.

2. Percentage and Magnitude of "Difficult" Cases.-Another issue we can examine is how contested or difficult copyright cases are compared to other civil cases. The AO data and other previous studies provide four points of comparison that give us insight into the possible uniqueness of copyright cases. First, the AO data allow us to compare whether defendants answer at a different rate in non-copyright litigation. Second, data collected by other scholars allow us to compare the number of substantive decisions made by courts. Third, data collected by other scholars also allow us to compare the number of docket entries in cases to get a sense of the overall level of contentiousness. And finally, the AO data allow us to compare the rate of voluntary dismissals and trials.

We begin at the beginning of the case - the complaint and the response thereto. Among other things, the AO tracks whether the "issue is joined," which the AO defines as the filing of a formal answer to the plaintiff's complaint. $^{72}$ The AO data indicate that the issue was joined in $53.67 \%$ of comparable civil litigation cases observed from 2005 through 2008. For patent and trademark cases during that period, the percentage of joined cases was slightly higher (56.01\%). In the Commonplace copyright cases we observed, the defendant filed an answer in $57.70 \%$ of the cases. This is almost exactly the same as that observed in the patent and trademark AO data, and very similar to that observed for comparable civil litigation cases. Accordingly, based on the filing of an answer alone, copyright cases are contested at a similar rate to other types of civil litigation.

Continuing through the life of the case, we find two other ways to measure how contested or difficult litigation becomes. As discussed above, we coded both the number of substantive decisions the court made and the number of docket entries so as to gain insight into each copyright case's intensity. David Hoffman, Alan Izenma, and Jeffery Lidicker's Docketology study of civil litigation included data on how many lawsuits constituted "difficult cases" - cases with some level of contentiousness or

chances of winning decrease by about $66 \%$ when filing in those districts). That said, one should not attach too much significance to this finding, because the chances of a plaintiff win are small to begin with, given that most cases terminate without a win for either party.

72. Margo Schlanger, Inmate Litigation, 116 HARV. L. REV. 1555, 1595 n.117 (2003). 
difficult legal issues. ${ }^{73}$ Comparing these two data sets gives us insight into whether copyright cases are similar in intensity and difficulty to other civil cases.

First, the number of substantive decisions. Hoffman et al. coded, as we did, any nonministerial, substantive decisions by the district court in a given case. ${ }^{74}$ As Table 15 shows, the percentage of "difficult" or intense copyright cases is almost identical to the percentage the Docketology study found in other civil litigation. ${ }^{75}$ This would suggest that copyright litigation is no more likely to present "difficult cases" to the courts than other civil litigation.

Table 15: Number of Substantive Decisions Compared

\begin{tabular}{|l|c|c|}
\hline & $\begin{array}{c}\text { Hoffman et al., } \\
\text { Docketology } \\
(\mathbf{2 0 0 7 )} \\
(\boldsymbol{n}=\mathbf{9 8 0})\end{array}$ & $\begin{array}{c}\text { Commonplace } \\
\text { Copyright } \\
\text { Cases } \\
(\boldsymbol{n}=\mathbf{3 8 3})\end{array}$ \\
\hline $\begin{array}{l}\text { “Difficult cases"_cases with at } \\
\text { least one substantive decision } \\
\text { (“hard order") }\end{array}$ & $49.39 \%$ & $50.65 \%$ \\
\hline $\begin{array}{l}\text { Average number of substantive } \\
\text { decisions ("hard orders") per } \\
\text { “difficult case” }\end{array}$ & 2.28 & 4.65 \\
\hline
\end{tabular}

That said, when copyright cases get "difficult," the data indicate that they require a lot more work, and perhaps generate a lot more friction from the parties, than other "difficult" civil cases. As seen in Table 15, the average number of substantive decisions per "difficult case" is much greater in copyright litigation - almost double that observed for other civil cases from the Docketology study. This suggests that if a copyright case is difficult, it is really difficult, perhaps because it involves complex legal and factual issues. Or maybe when a copyright litigation gets contentious, it becomes very contentious, and thus requires much more effort to ultimately resolve.

Next, the number of docket entries. As the Docketology study notes, this variable is a very crude tool by which to measure case difficulty or intensity across courts, as different courts follow very different practices for

73. See Hoffman et al., supra note 9, at 710 (defining "difficult" cases as those that contained "hard" orders, which were orders beyond mere "ministerial orders," such as orders on motions for dismissal or summary judgment).

74. Id. at 713.

75. See id. at 710 (indicating that 484 out of 980 cases contained at least one "hard" order). 
numbering entries in their dockets. ${ }^{76}$ With that caveat in mind, the comparison does show some differences: Docketology observed that about $61.22 \%$ of cases had fewer than 15 docket entries, ${ }^{77}$ but our Commonplace cases produced a much lower number $(26.11 \%)$. Therefore, to the extent that the number of docket entries provides an insight, copyright cases appear more difficult or intense than the average civil case.

One final point of comparison emerges at the end of the case, and it too establishes that copyright cases are more contentious then other civil litigation: the percentage of cases going to trial. While we observed a very low percentage of Commonplace trial cases $(4.81 \%)$, the general litigation $\mathrm{AO}$ data for the same period reported only $1.52 \%$ of civil cases resulting in a bench or jury trial. This difference, which is statistically significant ${ }^{78}$ is another indicator either that copyright cases involve uncertainties requiring court intervention or that copyright litigants are more willing to push hard. Even patent and trademark cases demonstrated a lower trial percentage of only $2.32 \% .^{79}$

Together, these four points of comparison suggest that copyright cases get contentious at a rate similar to that of other civil litigation, and patent and trademark litigation in particular. Within those contentious cases, however, we see statistically significant differences in the number of substantive decisions, the number of docket entries, and the number of trials, indicating that they become more contentious or "difficult" than civil cases more generally. This difference may be due to the fact- or standarddriven nature of copyright law, or perhaps to the complexity of the law in comparison to commonly litigated fields like commercial law. ${ }^{80}$ In any event, once a copyright case gets hard, it apparently gets really hard and more difficult to resolve.

3. Termination.-Finally, how and when do copyright cases terminate? The vast majority of Commonplace copyright cases terminated voluntarily, with $80.16 \%$ ending in an explicit settlement, agreed judgment, or voluntary dismissal. In comparison, the AO data from 2005 to 2008 reported a voluntary termination rate of $78.05 \%$ for comparable civil litigation $^{81}$ and $88.48 \%$ for patent and trademark. While there is some

76. Id. at 709 .

77. See id. (finding that roughly 600 out of 980 cases contained less than 15 docket entries).

78. Pearson's chi-square reports a $p$-value of $<0.0001$.

79. Pearson's chi-square reports a $p$-value of 0.0174 .

80. See supra note 63.

81. This does not include those cases in which the type of termination was coded by the AO as "other," because it is unclear in those cases whether the termination was voluntary. Voluntary termination included cases coded by the $\mathrm{AO}$ as terminating by settlement, voluntarily, or by consent. Involuntary termination included cases coded as terminating because of lack of jurisdiction, remand, motion before trial, jury verdict, directed verdict, court trial, appeal affirmed from magistrate judge, or appeal denied from magistrate judge. Other studies have reported 
variance, particularly when compared to patent and copyright cases, these percentages are close.

Copyright cases, however, take longer to get there. We observed the median pendency of Commonplace copyright cases to be 288 days. The AO reports a median pendency for a comparable civil litigation of $251 .{ }^{82}$ The median pendency was also shorter for patent and trademark cases, at 217 days. $^{83}$

So the median Commonplace copyright case took 37 days longer (a little over a month) to terminate than the median comparable civil litigation suit and 61 days longer (about two months) to terminate than patent and trademark cases. In the end, however, copyright cases produce similar results - voluntarily dismissing at a similar rate as other civil cases. These results reinforce those above: copyright cases are simply more difficult to resolve.

\section{B. The Role of Party Size and Industry}

Some of the most unexpected data reported in Part III involve party characteristics such as size and industry. The following discussion delves more deeply into those data, revealing some fallacies in common assumptions about copyright litigants and demonstrating that some party characteristics bear a significant relationship to case outcomes.

1. Party Size.-Both the popular literature and scholarly accounts portray major media companies as aggressive drivers of expansive copyright, dominating the landscape and dictating legal outcomes. ${ }^{84}$ The litigation data, however, tell a more nuanced tale. Major media companies are certainly active, but only in specific, targeted spheres, and are not as ubiquitous as the size of their copyright portfolios and tales of their

different settlement rates, but without knowing the specific methodology for determining what is a "settlement," comparison to our data becomes difficult. See, e.g., Kevin M. Clermont, Litigation Realities Redux, 84 Notre DAME L. ReV. 1919, 1954-55 (2009) (finding a settlement rate of approximately 67\%); see also Theodore Eisenberg \& Charlotte Lanvers, What is the Settlement Rate and Why Should We Care?, 6 J. EMPIRICAL LEGAL STUD. 111, 115-19 (2009) (discussing difficulties of defining what dispositions constitute a "settlement").

82. An unpaired $t$-test reports a two-tailed $P$ value of 0.0047 .

83. An unpaired $t$-test reports a two-tailed $P$ value of less than 0.0001 .

84. See, e.g., Ronald V. Bettig, Copyrighting Culture: The Political Economy of INTELLECTUAL PROPERTY 38 (1996) (reiterating the scholarly consensus that "six to ten... companies-will soon produce, own, and distribute the bulk of the culture and information circulating in the global market"); TRAJCE CVETKOVSKI, COPYRIGHT AND POPULAR MEDIA: Liberal Villains AND TECHNOLOGiCAL CHANGE 103 (2013) (noting how a small number of major corporations have continued to control copyrights and media consumption and cultivate an anticompetitive market despite modern antitrust legislation); Fiona Macmillan, Copyright and Corporate Power, in COPYRIGHT IN THE CUlTURAL INDUSTRIES 99, 107 (Ruth Towse ed., 2002) (arguing that companies are conglomerating aggressively both horizontally and vertically in order to gain private ownership of copyright interests and cultural output on a global scale). 
dominance might suggest. In contrast, smaller firms are surprisingly active, and both small firms and individuals have a statistically significant impact on various case outcome variables.

Start with the big boys. Fortune 1000 firms and their subsidiaries were the largest plaintiffs in $65.52 \%$ of the 957 cases we coded, suggesting an active and dominant industry of major media companies. ${ }^{85}$ But the vast majority of those cases (512) were File Sharing cases - the routine, cookiecutter lawsuits that media companies abandoned after 2008. One can therefore safely ignore those cases when discussing today's litigation trends. Of the remaining cases, 60 represented a different kind of cookiecutter litigation: the Performing Rights lawsuits in which bars and restaurants were accused of failing to pay licenses for public performances of musical works. So 572 of the 628 cases that Fortune 1000 companies filed were what one might call "cost of doing business" cases - where there is infringement to be combated, but it is low-level, and, if the allegations are true, liability is not seriously in doubt. One can add to this category another 15 cases in which leading software companies like Microsoft and Adobe sued small-scale online sellers of pirated software, a similarly formulaic form of repeat litigation.

That said, we observed a few instances of cutting-edge major media litigation, where the allegations, even if true, were hardly routine and did not necessarily establish infringement under current law. For example, there were 2 gray-market importation suits. ${ }^{86}$ And some suits in which liability was certain might nonetheless have raised unsettled issues, like the File Sharing cases that involved subpoenas to third-party ISPs ${ }^{87}$ or high jury awards for statutory damages. ${ }^{88}$ But these were rare exceptions; almost all

85. Six companies control $90 \%$ of the content in the television, film, radio, and news industries: CBS, Disney, General Electric, News Corp., Time Warner, and Viacom. Ashley Lutz, These 6 Corporations Control 90\% of the Media in America, BuS. INSIDER (June 14, 2012, 9:49 AM), http://www.businessinsider.com/these-6-corporations-control-90-of-the-media-in-amer ica-2012-6. All are Fortune 1000 companies. We therefore use our "Fortune 1000" category for Party Size as a proxy for major media companies. Such a proxy might capture additional companies as well, but this overinclusiveness is not a problem because our conclusion is that major media is less active than one would expect, not more.

86. These suits should be seen not as run-of-the-mill enforcement cases, but as part of a concerted effort on the part of major media companies to make new law-namely, to establish that copyright law forbids certain unauthorized gray-market imports. Note that this effort ultimately failed. See Kirtsaeng v. John Wiley \& Sons, Inc., 133 S. Ct. 1351, 1358 (2013) (holding that the "first sale" doctrine protects an importer who purchases foreign versions of textbooks and resells them in the United States from copyright liability).

87. E.g., In re Charter Commc'ns, Inc., 393 F.3d 771, 772-73 (8th Cir. 2005) (reversing a subpoena issued by the district court to an Internet service provider to turn over information about subscribers file sharing via peer-to-peer networks). But see, e.g., Capitol Records, Inc. v. Doe, No. 07-cv-1570-JM, 2007 WL 2429830, at*1 (S.D. Cal. Aug. 24, 2007) (granting the plaintiff permission to serve a subpoena on a third-party Internet service provider to turn over information sufficient to reveal the identity of the anonymous defendant).

88. E.g., Sony BMG Music Entm’t v. Tenenbaum, 660 F.3d 487 (1st Cir. 2011) (holding that 
the major media cases were routine, small-scale efforts to combat clear infringement. For the most part, then, the courtroom is where big media collects the spoils rather than fights the war. With that in mind, perhaps it is no surprise that regression analysis shows that having a Fortune 1000 plaintiff produces at least one statistically significant result: such cases are 164 days shorter on average than other cases. ${ }^{89}$

Another way of measuring the role of major media is to study the defendants it targets in Commonplace cases, as set forth in Table 16. For one thing, major media never files suit against itself; there were no cases in which Fortune 1000 companies were adversaries. An even more surprising finding is that only $5.48 \%$ of the cases involved a Fortune 1000 plaintiff against an individual defendant (the Goliath v. David cases) - and the opposite proposition (David v. Goliath) occurred just as often, if not slightly more $(6.01 \%){ }^{90}$

\section{Table 16: Face-Offs-Who Sues Whom? Commonplace Cases $(n=383)$}

\begin{tabular}{|c|c|c|}
\hline \multirow{2}{*}{$\begin{array}{c}\text { Fair Fights- } \\
\text { Both Parties Are: }\end{array}$} & Fortune 1000 & $0.0 \%$ \\
\cline { 2 - 3 } & Small Firm & $50.91 \%$ \\
\cline { 2 - 3 } & Individual & $3.13 \%$ \\
\hline \multicolumn{2}{|c|}{ Goliath v. David (Fortune 1000 v. Individual) } & $54.05 \%$ \\
\hline \multicolumn{2}{|c|}{ David v. Goliath (Individual v. Fortune 1000) } & $5.48 \%$ \\
\hline
\end{tabular}

This is not to say that the influence of major media companies in copyright law has necessarily been exaggerated. Our study focuses on filed cases only, and industry power clearly enables major media companies to resolve many disputes without filing suit. ${ }^{91}$ And their influence over domestic legislation and international policymaking is well documented. ${ }^{92}$

it was reversible error for a district court to reduce statutory damages under the due process clause with a motion for remittitur pending); Capitol Records, Inc. v. Thomas-Rasset, 692 F.3d 899 (8th Cir. 2012) (affirming damages of $\$ 222,000$ for twenty-four infringements).

89. See infra Appendix B, Regression 3. At a confidence level of $95 \%$, the overall range is 21.34 to 306.21 days shorter, with 163.77 as the midpoint. Note that this regression-like all the regressions we performed - controls for the industry of the parties, the number of parties, the size of the parties, the number of works at issue, whether it was an intra-industry dispute, whether the works are high authorship, whether the author is a plaintiff, and whether the case was filed in the two hottest districts.

90. The two figures have a margin of error of $\pm 2.25 \%$ and $\pm 2.35 \%$ respectively.

91. See, e.g., Gibson, supra note 11, at 890-91 (highlighting the nearly universal practice among major media companies of acquiring licenses from copyright holders prior to using copyrighted works, rather than relying on fair use doctrine).

92. See, e.g., JeSsiCa Litman, Digital COPYRight 36 (2001) (explaining how the 1909 Copyright Act, and nearly every subsequent incarnation of the Copyright Act since, relied on 
But outside the File Sharing and Performing Rights context, they rarely exercise this power in court.

Who does go to court? Small firms. Setting aside the bygone File Sharing cases, small firms are far and away the most common litigants, constituting the largest plaintiff $55.73 \%$ of the time and the largest defendant $73.93 \%$ of the time. ${ }^{94}$ Indeed, Table 16 reveals that half of the Commonplace cases involve small firms as both the biggest plaintiff and the biggest defendant. Moreover, not only are small firms ubiquitous, but regression analysis reveals that when a small firm is the largest plaintiff, the chances that the defendant will win the case decline by more than $70 \%{ }^{95}$

Individuals, too, have a measurable impact on certain litigation outcomes, but here the story is what one would expect. For example, when the largest plaintiff is an individual, the chances of an adversarial termination increase by a factor of 3.61. ${ }^{96}$ Of course, that finding alone does not tell us which party prevails, but a separate regression reveals that when the largest plaintiff is an individual, the chances of a defendant win increase sixfold. ${ }^{97}$ This is an unsurprising finding: when an individual plaintiff files a case, he or she will be facing a bigger defendant (either a small firm or a Fortune 1000 company) about $85 \%$ of the time, and a disparity of resources may follow.

There is, however, another possible explanation for the lack of success of individual plaintiffs: they may be too attached to the copyrighted work and thus may fail to dispassionately evaluate their chances of success in litigation. Research suggests that when individuals own the copyright to a work, they experience an endowment effect that causes them to value the copyright at a level higher than an objective assessment would merit—and

"interindustry negotiations" and was shaped largely by predominating industry interests).

93. Note also that the Fortune 1000 classification was the only Party Size category that had no statistically significant relation to our various measures of case process and outcome- e.g., whether the case terminated with an adversarial ruling, whether the chances of a plaintiff win or defendant win increased, how long the case lasted, and so forth. As discussed below, the other two Party Size categories (Small Firm and Individual) had some significant relation to at least one of these variables.

94. These figures change to $64.23 \%$ and $72.06 \%$ if we count Commonplace cases only. Keep in mind that "Small Firm" refers to any party that is not a Fortune 1000 company or an individual. See supra note 21 .

95. See infra Appendix B, Regression 1. The relative-risk ratio is 0.26 (meaning that the defendant's chances of winning decrease by $74 \%$ ), and this result is significant at a confidence level of $99 \%$. Nevertheless, one should not attach too much significance to this finding, because the chances of a defendant win are small to begin with, given that most cases terminate without a win for either party.

96. Valid at a $99 \%$ confidence level. See infra Appendix B, Regression 4.

97. The relative-risk ratio is 6.11 and the confidence level is $99 \%$. See infra app. B, Regression 2. Keep in mind that the chances of a defendant win are small to begin with, so a sixfold increase may not be large in an absolute sense. 
this inflated value is due, at least in part, to an ownership bias. ${ }^{98}$ The presence of nonindividuals in the plaintiff group may help mute any such tendency, resulting in fewer bad cases being filed.

One final variable helps us explore the endowment effect theory: whether the author of an allegedly infringed work is one of the plaintiffs (not necessarily the largest), which is true in $81.72 \%$ of the Commonplace lawsuits. Regression analysis shows that the presence of this factor decreases the chances that the plaintiff will prevail by about $70 \% .{ }^{99}$ This finding is consistent with research that finds an even stronger endowment effect for those who create copyrighted works, as opposed to those who merely own them. ${ }^{100}$

2. Party Industry (High-IP and Low-IP).-Our analysis concludes with an exploration of another surprising finding: the prevalence of low-IP industries and works in copyright litigation. In the Commonplace category, the industry that is the most common plaintiff and most common defendant is Apparel/Fashion/Textiles, at $13.58 \%$ on both lists. Architecture and Industrial Design also rank high. ${ }^{101}$ (Recall that we saw similar results in the Subject Matter classification, where Apparel/Fashion/Textiles, Architectural Works, and Industrial Design combined to make up almost $30 \%$ of all litigated works in Commonplace cases.) $)^{102}$

The conventional wisdom is that these industries operate at copyright's periphery - thus the low-IP label. Apparel is famously difficult to protect under copyright law, ${ }^{103}$ and industrial design and architectural works are

98. See Christopher Buccafusco \& Christopher Sprigman, Valuing Intellectual Property: An Experiment, 96 CORNELL L. REV. 1, 27 (2010) (finding that both regret aversion-the desire to avoid feeling unhappy if one's choice produces an undesirable result - and optimism or ownership bias - the tendency to value things associated with oneself more highly - distinctly contribute to the valuation asymmetries inherent to the endowment effect). Note, however, that the potency and validity of endowment effects generally has recently come under fire. See Gregory Klass \& Kathryn Zeiler, Against Endowment Theory: Experimental Economics and Legal Scholarship, 61 UCLA L. REV. 2, 6 (2013) (asserting that "the best available evidence" no longer supports the "generic" application of the endowment effect).

99. See infra Appendix B, Regressions $1 \& 2$. As explained previously, see supra note 71, we ran two regressions with Winning Party as the dependent variable, but both produced statistical significance at the $95 \%$ confidence level and a relative-risk ratio of about 0.30 . Again, remember that the chances of a plaintiff win are always small, so a $70 \%$ decrease may not be as large as it first appears.

100. See Buccafusco \& Sprigman, supra note 7, at 31. Another interpretation of this data is that U.S. copyright law does a poor job of protecting moral rights-i.e., vindicating the special connection that authors have to their creative works. (We are indebted to Justin Hughes for pointing this out.)

101. For the complete rundown, see supra Tables $3 \& 4$.

102. See supra Table 5 .

103. See, e.g., Raustiala \& Sprigman, supra note 10, at 1700 (discussing how copyright law does not protect various creative elements of apparel, such as the "cut of a sleeve, [or] the shape of a pant leg"). 
likewise hampered by functionality constraints and other exceptions to copyright's usual reach. ${ }^{104}$ Yet all three are among the leading industries in everyday copyright litigation. This suggests a level of litigation disproportionate to the value of the copyrights being litigated.

Of course, the lists also feature less surprising industries at the top, like Software, Music, and Film. And there is a lot of clustering: on both lists, each industry is within the margin of error of at least one other. Therefore, to get more of a sense of the overall balance between low-IP and high-IP industries, we converted the industry field into a single binary variable: Core/Non-Core. This is a common practice among those examining the economic impact of copyright-based industries, and we followed the usual conventions by classifying as Core the following high-IP industries: Advertising and Marketing, Commercial Arts, Film and TV, Fine Arts, Music, Performing Arts, Publishing, and Software. ${ }^{105}$

The results of this second-order coding appear in Table 17. One can see that the largest plaintiff in a lawsuit is almost as likely to be from outside the Core copyright industries $(45.17 \%)$ as inside $(54.83 \%)$; indeed, the difference is within the margins of error ( $\pm 4.98 \%$ for both figures). The largest defendant is actually slightly more likely to be from a Non-Core industry $(54.31 \%)$ than Core $(45.69 \%)$, although the results are again within the margins of error $( \pm 4.99 \%$ in both instances).

104. Until 1990, architectural works (except as two-dimensional blueprints) were considered almost completely uncopyrightable under U.S. law. See Todd Hixon, Note, The Architectural Works Copyright Protection Act of 1990: At Odds with the Traditional Limitations of American Copyright Law, 37 ARIZ. L. REV. 629, 629 n.2 (1995) (observing that copyright protection attached to architectural works prior to 1990 only if the structure's "monumental or sculptural qualities" so surpassed its use and function as to render it a "pictorial, graphic or sculptural work"). Even after 1990, architectural works have continued to be subject to certain specific limitations not applicable to other works. See, e.g., 17 U.S.C. § 120(a) (2012) (permitting the making and distribution of pictorial representations of otherwise copyrighted architectural works so long as the work is "located in or ordinarily visible from a public place"). Other works of industrial design are similarly limited, most significantly by the useful article doctrine. See, e.g., 17 U.S.C. $\$ 101$ (defining a "useful article" as an article that has an "intrinsic utilitarian function that is not merely to portray the appearance of the article or to convey information"); Alfred C. Yen, Copyright Opinions and Aesthetic Theory, 71 S. CAL. L. REV. 247, 275 (1998) (noting that the useful article doctrine was "the result of administrative, legislative, and judicial decisions to deny copyright protection to works of industrial design even if they are aesthetically valuable").

105. This definition follows the well-known World Intellectual Property Organization (WIPO) guidelines. See World Intellectual Prop. Org., Guide on Surveying the ECONOMIC CONTRIBUTION OF THE COPYRIGHT-BASED INDUSTRIES 28-29 (2003) (defining "core copyright industries" according to the following overarching categories: "press and literature;" "music, theatrical productions, operas;" "motion picture and video;" "photography;" "software and databases;" "visual and graphic arts;" "advertising services;" and "copyright collective management societies"). Prominent economic studies that use the WIPO definition, or an even narrower one, include: ECON. \& STATISTICS ADMIN. \& U.S. PATENT AND TRADEMARK OfFICE, INTELLECTUAL PROPERTY AND THE U.S. ECONOMY: INDUSTRIES IN FOCUS (2012), and STEPHEN E. SiweK, Copyright Industries IN THE U.S. ECONOMY: The 2011 RePORT (2011). Such studies sometimes depart from the WIPO guidelines at the margins, but not over issues that impact our data. 
Table 17: Core/Non-Core Industries Commonplace Cases $(n=383)$

\begin{tabular}{|c|c|c|}
\hline \multirow{2}{*}{ Industry of Largest Plaintiff } & Core & $54.83 \%$ \\
\hline & Non-Core & $45.17 \%$ \\
\hline \multirow{2}{*}{$\begin{array}{l}\text { Industry of Largest } \\
\text { Defendant }\end{array}$} & Core & $45.69 \%$ \\
\hline & Non-Core & $54.31 \%$ \\
\hline
\end{tabular}

We also combined the industry data to see how often a dispute occurred between parties of the same industry. As Table 18 shows, such intra-industry disputes occurred in $74.15 \%$ of Commonplace cases - a high figure, given that the coding used seventeen different industry classifications. Reducing those classifications to just Core and Non-Core reveals that disputes are just as likely to occur within Non-Core industries (43.34\%) as within Core (43.86\%).

\section{Table 18: Intra- and Extra-Industry Disputes Commonplace Cases $(n=383)$}

\begin{tabular}{|l|l|}
\hline Intra-Industry & $74.15 \%$ \\
\hline Extra-Industry & $25.85 \%$ \\
\hline Core v. Core & $43.86 \%$ \\
\hline Non-Core v. Non-Core & $43.34 \%$ \\
\hline Total & $87.20 \%$ \\
\hline
\end{tabular}

These findings have two implications. First, low-IP industries may litigate copyright issues at a disproportionately high rate precisely because they are low-IP. Legal outcomes are less certain for industries and works at the periphery of copyright law, and litigation is one way to reduce that uncertainty. And low-IP, Non-Core industries are probably more diffuse and less homogenous, such that filing suit may perform an important communications function - a clear signal that an unfamiliar plaintiff is serious. In contrast, Core copyright industries are more likely to comprise a small number of repeat players who are accordingly more able to resolve disputes before suits get filed. (Consider again the concentration of copyright ownership in major media companies.) And Core industries presumably also experience less uncertainty about copyright law, reserving their litigation resources for the kinds of cookie-cutter, cost-of-doingbusiness cases not reflected in the surprisingly diverse Commonplace category.

Second, the prevalence of low-IP industries and works in copyright litigation highlights the importance of limiting doctrines in copyright law. 
The clothing cases tend to involve copyrights in simple, two-dimensional patterns, which the rightholder deploys to sue manufacturers and retailers galore. Perhaps that is as it should be, but it highlights the importance of both aspects of copyright's originality requirement: (1) the low threshold for creativity and (2) the need to prove that the creativity is the author's own, rather than a copy of a preexisting work, as many of the clothing patterns probably resemble something that has been done before. ${ }^{106}$ Both researcher and practitioner might also be well-advised to become more familiar with "thin" theories of infringement analysis applicable in a low-IP context, such as those requiring "virtual identity" rather than "substantial similarity" to prove infringement. ${ }^{107}$

Likewise, the primacy of industrial design and architecture cases suggests attention to limiting doctrines. The useful article doctrine is not just an academic concept that helps students learn the difference between patent and copyright; it has a real importance to everyday litigation. And mechanisms like the idea/expression dichotomy, fact/expression dichotomy, merger doctrine, and other limitations on functional goods ${ }^{108}$ assume importance outside the software context.

\section{Conclusion}

Our study represents a first step in the direction of a more robust, empirically accurate understanding of what copyright looks like in the courtroom. Our results show that copyright litigation differs in some significant ways from other litigation and that it also varies from what copyright experts might expect. We hope that this data will inform the ongoing conversation about the direction of copyright law and provide a basis for future research along the same lines.

106. See Feist Publ'ns, Inc. v. Rural Tel. Serv. Co., 499 U.S. 340, 345 (1991) (discussing the two aspects of copyright's originality requirement and emphasizing both that the creativity threshold is "extremely low" and "even a slight amount [of creativity] will suffice").

107. See, e.g., Satava v. Lowry, 323 F.3d 805, 812 (9th Cir. 2003) (granting a sculptor a "thin" copyright in realistic sculptures of jellyfish in so far as the sculpture's artistic characteristics were not influenced by jellyfish physiology, and holding that infringement of such a copyright requires "virtually identical copying"); Ets-Hokin v. Skyy Spirits, Inc., 323 F.3d 763, 764-66 (9th Cir. 2003) (holding that a photographer's copyright in commercial photographs of a blue vodka bottle was "thin" and therefore limited to "virtual identical copying").

108. See, e.g., Harper House, Inc. v. Thomas Nelson, Inc., 889 F.2d 197, 205 (9th Cir. 1989) (holding that factual compilations or compilations consisting of "uncopyrightable elements" receive limited protection and that infringement of such works requires "bodily appropriation of expression" (internal quotation marks omitted)). 


\section{Appendix A: Coded Fields}

\begin{tabular}{|c|c|}
\hline Coded Field & Data Type/Categories \\
\hline Case Name & Alphanumeric \\
\hline Filing Date & Date \\
\hline Court & Alphanumeric \\
\hline Judge & Alphanumeric \\
\hline No. of Plaintiffs & Numeral \\
\hline No. of Defendants & Numeral \\
\hline No. of "Doe" Defendants & Numeral \\
\hline File-Sharing Suit? & Binary \\
\hline $\begin{array}{l}\text { Performing Rights Organization } \\
\text { Suit? }\end{array}$ & Binary \\
\hline Subject Matter & $\begin{array}{l}\text { Literary-Industry Publications } \\
\text { Literary_-Books/Newspapers/Journals } \\
\text { Literary-Software } \\
\text { Literary_Other } \\
\text { Musical } \\
\text { Dramatic } \\
\text { Pantomimes \& Choreographic } \\
\text { PGS-Apparel/Fashion/Textiles } \\
\text { PGS_Commercial Art } \\
\text { PGS-Fine Art } \\
\text { PGS-Industrial } \\
\text { PGS-Other } \\
\text { Motion Pictures \& Other Audiovisual } \\
\text { Sound Recordings } \\
\text { Architectural } \\
\text { Multiple-Musical and Sound } \\
\text { Recording } \\
\text { Multiple-Website } \\
\text { Multiple-Other }\end{array}$ \\
\hline High Authorship? & Binary \\
\hline No. of Works at Issue & Numeral \\
\hline Plaintiff Author? & Binary \\
\hline $\begin{array}{l}\text { Size of Plaintiff } \\
\text { Size of Defendant }\end{array}$ & $\begin{array}{l}\text { Fortune } 1000 \text { (or subsidiary) } \\
\text { Small Firm } \\
\text { Individual }\end{array}$ \\
\hline
\end{tabular}




\begin{tabular}{|c|c|}
\hline Coded Field & Data Type/Categories \\
\hline $\begin{array}{l}\text { Industry of Plaintiff } \\
\text { Industry of Defendant }\end{array}$ & $\begin{array}{l}\text { Film and TV } \\
\text { Music } \\
\text { Publishing } \\
\text { Software-Video Games } \\
\text { Software-Other } \\
\text { Advertising and Marketing } \\
\text { Apparel/Fashion/Textiles } \\
\text { Architecture } \\
\text { Commercial Art } \\
\text { Fine Arts } \\
\text { Individual } \\
\text { Industrial Design } \\
\text { Performing Arts } \\
\text { Food \& Drink } \\
\text { Public Sector } \\
\text { Other-Retail/Wholesale/Durable } \\
\quad \text { Goods } \\
\text { Other- } \\
\quad \text { Professional/Scientific/Technical } \\
\text { Other-Misc. }\end{array}$ \\
\hline Type of Suit & $\begin{array}{l}\text { Fed. Copyright Infringement Only } \\
\text { Fed. and State Copyright Infringement } \\
\text { State Copyright Infringement Only } \\
\text { Ownership Dispute (Federal and/or } \\
\text { State) } \\
\text { Other }\end{array}$ \\
\hline Declaratory Judgment? & Binary \\
\hline Foreign & $\begin{array}{l}\text { No Foreign Claim } \\
\text { Foreign Copyright Infringement } \\
\text { Foreign Moral Rights } \\
\text { Both Foreign Copyright and Moral } \\
\quad \text { Rights }\end{array}$ \\
\hline Section 106(1) Claim? & Binary \\
\hline Section 106(2) Claim? & Binary \\
\hline Section 106(3) Claim? & Binary \\
\hline Section 106(4) Claim? & Binary \\
\hline Section 106(5) Claim? & Binary \\
\hline Section 106(6) Claim? & Binary \\
\hline Section 106A Claim? & Binary \\
\hline DMCA Claim? & Binary \\
\hline Secondary Liability Claim? & Binary \\
\hline
\end{tabular}




\begin{tabular}{|l|l|}
\hline \multicolumn{1}{|c|}{ Coded Field } & \multicolumn{1}{c|}{ Data Type/Categories } \\
\hline Trademark Claim? & Binary \\
\hline Contract Claim? & Binary \\
\hline Additional Claim(s)? & Binary \\
\hline Counterclaim(s) and/or Cross- & Binary \\
\hline Claim(s)? & Statutory-Willful \\
& Statutory-Regular \\
Plead Damages & Statutory-Innocent \\
& Actual Damages \\
& None \\
\hline Plead Injunction? & Binary \\
\hline Answer Filed? & Binary \\
\hline Consolidated or Transferred? & Binary \\
\hline & Summary Judgment \\
& $12($ b)(6) Motion \\
& $12($ c) Motion \\
& JNOV \\
\hline \multirow{5}{*}{ Termination Type } & Default Judgment \\
& Lack of Jurisdiction \\
& Other Dismissal \\
& TRO/Preliminary Injunction \\
& Multiple of the Above \\
& None of the Above \\
\hline & Yes, and no JNOV Filed \\
& No \\
& Yes, and JNOV Granted \\
& Yes, and JNOV Denied \\
\hline & Trial \\
& Summary Judgment \\
& $12($ b)(6) Dismissal \\
& 12 (c) Dismissal \\
& JNOV \\
& Default Judgment \\
& Lack of Jurisdiction \\
& Settlement \\
& Agreed Judgment \\
& Voluntary Dismissal \\
& Other Dismissal \\
& Still Open \\
\hline
\end{tabular}




\begin{tabular}{|l|l|}
\hline \multicolumn{1}{|c|}{ Coded Field } & \multicolumn{1}{c|}{ Data Type/Categories } \\
\hline \multirow{3}{*}{ Winning Party } & Plaintiff(s) \\
& Defendant(s) \\
& Neither/Agreed Judgment \\
\hline Termination Date & Date \\
\hline & Statutory_Willful \\
& Statutory-Regular \\
& Statutory_Innocent \\
Outcome Damages & Actual Damages \\
& $>0$ (but can't tell more) \\
& Agreed Damages \\
& None \\
\hline \multirow{3}{*}{ Outcome Injunction } & Yes \\
& No \\
\hline No. of Docket Entries & Agreed Injunction \\
\hline No. of Substantive Decisions & Numeral \\
\hline
\end{tabular}




\section{Appendix B: Regressions}

\section{Regression 1: Winning Party (Plaintiff as Small Firm)}

\begin{tabular}{|c|c|c|c|c|c|c|}
\hline \multicolumn{3}{|c|}{ Multinomial Logistic Regression } & \multicolumn{4}{|c|}{$\operatorname{LR~chi~}^{2}(24)=62.87$} \\
\hline \multicolumn{3}{|c|}{ Number of Observations $=377$} & \multicolumn{4}{|c|}{ Prob. $>$ chi $^{2}=0.0000$} \\
\hline \multicolumn{3}{|c|}{ Log Likelihood $=-175.24331$} & \multicolumn{4}{|c|}{ Pseudo $R^{2}=0.1521$} \\
\hline Winning Party & RRR & Std. Err. & $\mathbf{z}$ & $\mathbf{P}>|\mathbf{z}|$ & \multicolumn{2}{|c|}{ 95\% Conf. Interval } \\
\hline \multicolumn{7}{|l|}{ Defendant } \\
\hline P Industry & .4515904 & .311825 & -1.15 & 0.250 & .1166774 & 1.747844 \\
\hline D Industry & 1.208421 & .8050844 & 0.28 & 0.776 & .3274341 & 4.459775 \\
\hline $\mathrm{P}=$ Small Firm $?$ & .2620272 & .1366195 & -2.57 & 0.010 & .0943049 & .728045 \\
\hline Defendant Size: 2 & .6263944 & .4598092 & -0.64 & 0.524 & .1485995 & 2.640452 \\
\hline Defendant Size: 3 & .4105019 & .2304616 & -1.59 & 0.113 & .1365961 & 1.23365 \\
\hline High Authorship? & 1.420268 & .6987514 & 0.71 & 0.476 & .5414912 & 3.725197 \\
\hline Intra-Industry? & .9508619 & .4672255 & -0.10 & 0.918 & .3629628 & 2.490995 \\
\hline No. Plaintiffs & 1.119019 & .1280614 & 0.98 & 0.326 & .8941806 & 1.400392 \\
\hline $\begin{array}{l}\text { No. Non-Doe } \\
\text { Defendants }\end{array}$ & 1.089563 & .0451487 & 2.07 & 0.038 & 1.004571 & 1.181745 \\
\hline No. Works & .9644603 & .0290061 & -1.20 & 0.229 & .9092525 & 1.02302 \\
\hline $\mathrm{P}=$ Author? & 4.519685 & 4.913307 & 1.39 & 0.165 & .5367538 & 38.05759 \\
\hline C.D. Cal/SDNY & .5254648 & .2890864 & -1.17 & 0.242 & .1787524 & 1.544668 \\
\hline Neither & \multicolumn{6}{|c|}{ (base outcome) } \\
\hline \multicolumn{7}{|l|}{ Plaintiff } \\
\hline P Industry & .3719349 & .2677939 & -1.37 & 0.170 & .0906985 & 1.525224 \\
\hline D Industry & 1.373708 & .9454388 & 0.46 & 0.645 & .3565043 & 5.293271 \\
\hline $\mathrm{P}=$ Small Firm $?$ & .5087637 & .2462818 & -1.40 & 0.163 & .1970005 & 1.313908 \\
\hline Defendant Size: 2 & 4689879 & $4.14 \mathrm{e}+09$ & 0.02 & 0.986 & 0 & . \\
\hline Defendant Size: 3 & 2539597 & $2.24 \mathrm{e}+09$ & 0.02 & 0.987 & 0 & . \\
\hline High Authorship? & .9762983 & .4338871 & -0.05 & 0.957 & .4085931 & 2.332782 \\
\hline Intra-Industry? & 1.079488 & .5700226 & 0.14 & 0.885 & .3834791 & 3.038743 \\
\hline No. Plaintiffs & .9912013 & .0511899 & -0.17 & 0.864 & .8957816 & 1.096785 \\
\hline $\begin{array}{l}\text { No. Non-Doe } \\
\text { Defendants }\end{array}$ & .9519452 & .0877568 & -0.53 & 0.593 & .7945888 & 1.140464 \\
\hline No. Works & 1.004684 & .0035991 & 1.30 & 0.192 & .9976544 & 1.011763 \\
\hline $\mathrm{P}=$ Author? & .2972404 & .1435951 & -2.51 & 0.012 & .115318 & .7661581 \\
\hline C.D. Cal/SDNY & .3378337 & .178836 & -2.05 & 0.040 & .1197044 & .9534454 \\
\hline
\end{tabular}




\section{Regression 2: Winning Party (Plaintiff as Individual)}

\begin{tabular}{|c|c|c|c|c|c|c|}
\hline \multicolumn{3}{|c|}{ Multinomial Logistic Regression } & \multicolumn{4}{|c|}{$\operatorname{LR~chi~}^{2}(24)=62.02$} \\
\hline \multicolumn{3}{|c|}{ Number of Observations $=377$} & \multicolumn{4}{|c|}{ Prob. $>$ chi $^{2}=0.0000$} \\
\hline \multicolumn{3}{|c|}{ Log Likelihood = -173.17161 } & \multicolumn{4}{|c|}{ Pseudo $R^{2}=0.1621$} \\
\hline Winning Party & RRR & Std. Err. & $\mathbf{z}$ & $\mathbf{P}>|z|$ & \multicolumn{2}{|c|}{ 95\% Conf. Interval } \\
\hline \multicolumn{7}{|l|}{ Defendant } \\
\hline P Industry & .4835872 & .355439 & -0.99 & 0.323 & .1145084 & 2.042265 \\
\hline D Industry & 1.565449 & 1.101145 & 0.64 & 0.524 & .3943657 & 6.214105 \\
\hline $\mathrm{P}=$ Individual $?$ & 6.112852 & 3.19189 & 3.47 & 0.001 & 2.196747 & 17.01014 \\
\hline Defendant Size: 2 & .935546 & .6901411 & -0.09 & 0.928 & .2203657 & 3.971791 \\
\hline Defendant Size: 3 & .482577 & .27386 & -1.28 & 0.199 & .158677 & 1.467639 \\
\hline High Authorship? & .8201587 & .4634445 & -0.35 & 0.726 & .2709643 & 2.482468 \\
\hline Intra-Industry? & .9613925 & .4777782 & -0.08 & 0.937 & .3629807 & 2.546349 \\
\hline No. Plaintiffs & 1.198717 & .1372954 & 1.58 & 0.114 & .9576878 & 1.500407 \\
\hline $\begin{array}{l}\text { No. Non-Doe } \\
\text { Defendants }\end{array}$ & 1.087402 & .0453143 & 2.01 & 0.044 & 1.002118 & 1.179944 \\
\hline No. Works & .9577102 & .0299122 & -1.38 & 0.167 & .9008417 & 1.018169 \\
\hline $\mathrm{P}=$ Author? & 3.519037 & 3.885952 & 1.14 & 0.255 & .4040836 & 30.64619 \\
\hline C.D. Cal/SDNY & .5317477 & .2976412 & -1.13 & 0.259 & .1775223 & 1.592789 \\
\hline Neither & \multicolumn{6}{|c|}{ (base outcome) } \\
\hline \multicolumn{7}{|l|}{ Plaintiff } \\
\hline P Industry & .3939316 & .282928 & -1.30 & 0.195 & .0963994 & 1.609783 \\
\hline D Industry & 1.699362 & 1.131693 & 0.80 & 0.426 & .4607087 & 6.268234 \\
\hline $\mathrm{P}=$ Individual $?$ & 1.125516 & .6443712 & 0.21 & 0.836 & .3664617 & 3.456803 \\
\hline Defendant Size: 2 & 2159755 & $1.16 \mathrm{e}+09$ & 0.03 & 0.978 & 0 & . \\
\hline Defendant Size: 3 & 1016597 & $5.46 \mathrm{e}+08$ & 0.03 & 0.979 & 0 & . \\
\hline High Authorship? & 1.010016 & .4670874 & 0.02 & 0.983 & .4080241 & 2.500179 \\
\hline Intra-Industry? & .9504486 & .4891109 & -0.10 & 0.921 & .3466501 & 2.605949 \\
\hline No. Plaintiffs & 1.002409 & .0488727 & 0.05 & 0.961 & .9110544 & 1.102924 \\
\hline $\begin{array}{l}\text { No. Non-Doe } \\
\text { Defendants }\end{array}$ & .9414298 & .0871142 & -0.65 & 0.514 & .785277 & 1.128634 \\
\hline No. Works & 1.004744 & .0040161 & 1.18 & 0.236 & .9969038 & 1.012647 \\
\hline $\mathrm{P}=$ Author? & .3078759 & .149652 & -2.42 & 0.015 & .1187475 & .7982278 \\
\hline C.D. Cal/SDNY & .3408466 & .1800397 & -2.04 & 0.042 & .121044 & .95978 \\
\hline
\end{tabular}




\section{Regression 3: Pendency of Case (Number of Days)}

\begin{tabular}{|c|c|c|c|c|c|c|}
\hline Source & \multicolumn{2}{|l|}{ SS } & \multicolumn{2}{|l|}{$d f$} & \multicolumn{2}{|c|}{ MS } \\
\hline Model & \multicolumn{2}{|l|}{3973067.22} & \multicolumn{2}{|l|}{12} & \multicolumn{2}{|c|}{331088.935} \\
\hline Residual & \multicolumn{2}{|l|}{59510065.2} & \multicolumn{2}{|c|}{364} & \multicolumn{2}{|c|}{163489.19} \\
\hline Total & \multicolumn{2}{|l|}{63483132.4} & \multicolumn{2}{|c|}{376} & \multicolumn{2}{|c|}{168838.118} \\
\hline \multicolumn{7}{|c|}{ Number of Observations $=377$} \\
\hline \multicolumn{7}{|c|}{$\mathrm{F}(12,364)=2.03$} \\
\hline \multicolumn{7}{|c|}{ Prob. $>\mathrm{F}=0.0213$} \\
\hline \multicolumn{7}{|c|}{$R^{2}=0.0626$} \\
\hline \multicolumn{7}{|c|}{ Adj $R^{2}=0.0317$} \\
\hline \multicolumn{7}{|c|}{ Root $\mathrm{MSE}=404.34$} \\
\hline $\begin{array}{l}\text { Pendency } \\
\text { Days }\end{array}$ & Coefficient & Std. Err. & $t$ & $\mathbf{P}>|t|$ & 95\% Con & Interval \\
\hline P Industry & 66.02923 & 76.16818 & 0.87 & 0.387 & -83.7557 & 215.8142 \\
\hline D Industry & 25.39834 & 71.6561 & 0.35 & 0.723 & -115.514 & 166.3102 \\
\hline $\mathrm{P}=\mathrm{F} 1000 ?$ & -163.773 & 72.43212 & -2.26 & 0.024 & -306.211 & -21.3351 \\
\hline $\begin{array}{l}\text { Defendant } \\
\text { Size: } 2 \\
\end{array}$ & 59.29194 & 87.34895 & 0.68 & 0.498 & -112.48 & 231.0639 \\
\hline $\begin{array}{l}\text { Defendant } \\
\text { Size: } 3\end{array}$ & 88.85074 & 65.69757 & 1.35 & 0.177 & -40.3437 & 218.0452 \\
\hline $\begin{array}{l}\text { High } \\
\text { Authorship? }\end{array}$ & -16.60375 & 49.93402 & -0.33 & 0.740 & -114.799 & 81.59163 \\
\hline Intra-Industry? & 68.82886 & 54.9465 & 1.25 & 0.211 & -39.2236 & 176.8813 \\
\hline No. Plaintiffs & 3.110344 & 5.82042 & 0.53 & 0.593 & -8.33553 & 14.55622 \\
\hline $\begin{array}{l}\text { No. Non-Doe } \\
\text { Defendants }\end{array}$ & 17.21604 & 6.046507 & 2.85 & 0.005 & 5.325567 & 29.10651 \\
\hline No. Works & .1208949 & .1068845 & 1.13 & 0.259 & -.089294 & .3310836 \\
\hline $\mathrm{P}=$ Author? & 58.44578 & 59.00443 & 0.99 & 0.323 & -57.5866 & 174.4781 \\
\hline $\begin{array}{l}\text { C.D. } \\
\text { Cal/SDNY }\end{array}$ & -44.53646 & 46.19138 & -0.96 & 0.336 & -135.372 & 46.29901 \\
\hline [Constant] & 183.1448 & 107.4053 & 1.71 & 0.089 & -28.0680 & 394.3575 \\
\hline
\end{tabular}




\section{Regression 4: Adversarial Termination}

\begin{tabular}{|c|c|c|c|c|c|c|}
\hline \multicolumn{3}{|c|}{ Logistic Regression } & \multicolumn{4}{|c|}{ 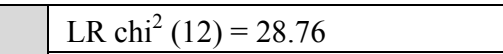 } \\
\hline \multicolumn{3}{|c|}{ Number of Observations $=377$} & \multicolumn{4}{|c|}{ Prob. $>$ chi $^{2}=0.0043$} \\
\hline \multicolumn{3}{|c|}{ Log Likelihood $=-131.26709$} & \multicolumn{4}{|c|}{ Pseudo $R^{2}=0.0987$} \\
\hline \multirow{2}{*}{$\begin{array}{l}\text { Termination } \\
\text { P Industry } \\
\end{array}$} & \multirow{2}{*}{$\begin{array}{c}\begin{array}{c}\text { Odds } \\
\text { Ratio }\end{array} \\
.4115909 \\
\end{array}$} & \multirow{2}{*}{$\begin{array}{l}\text { Std. Err. } \\
.2280665 \\
\end{array}$} & \multirow{2}{*}{$\begin{array}{c}\mathbf{z} \\
-1.60 \\
\end{array}$} & \multirow{2}{*}{$\begin{array}{l}\mathbf{P}>|\mathbf{z}| \\
0.109 \\
\end{array}$} & \multicolumn{2}{|c|}{ 95\% Conf. Interval } \\
\hline & & & & & .1389334 & 1.21934 \\
\hline D Industry & 1.507568 & .7992939 & 0.77 & 0.439 & .5333106 & 4.261607 \\
\hline $\mathrm{P}=$ Individual $?$ & 3.614075 & 1.419094 & 3.27 & 0.001 & 1.674043 & 7.802393 \\
\hline Defendant Size: 2 & .9983345 & .5977264 & -0.00 & 0.998 & .3087746 & 3.227829 \\
\hline Defendant Size: 3 & .667969 & .3111197 & -0.87 & 0.386 & .2680973 & 1.664256 \\
\hline High Authorship? & .9236191 & .3740652 & -0.20 & 0.844 & .4175965 & 2.042815 \\
\hline Intra-Industry? & .9266835 & .3589774 & -0.20 & 0.844 & .4337048 & 1.980016 \\
\hline No. Plaintiffs & 1.023399 & .0398336 & 0.59 & 0.552 & .9482307 & 1.104527 \\
\hline $\begin{array}{l}\text { No. Non-Doe } \\
\text { Defendants }\end{array}$ & 1.059632 & .0390154 & 1.57 & 0.116 & .9858571 & 1.138927 \\
\hline No. Works & 1.001435 & .0008754 & 1.64 & 0.101 & .9997211 & 1.003153 \\
\hline $\mathrm{P}=$ Author? & 1.784566 & 1.050091 & 0.98 & 0.325 & .563197 & 5.654637 \\
\hline C.D. Cal/SDNY & .5345003 & .2178181 & -1.54 & 0.124 & .2404743 & 1.18803 \\
\hline
\end{tabular}

